\title{
Gender differences in the skill content of jobs
}

\author{
Rita Pető ${ }^{1} \cdot$ Balázs Reizer $^{1}$
}

Received: 28 August 2019 / Accepted: 25 January 2021 / Published online: 26 February 2021

(c) The Author(s) 2021

\begin{abstract}
There is significant heterogeneity in actual skill use within occupations even though occupations are differentiated by the task workers should perform during work. Using data on 12 countries which are available both in the Programme for the International Assessment of Adult Competencies survey and International Social Survey Program, we show that women use their cognitive skills less than men even within the same occupation. The gap in skill intensity cannot be explained by differences in worker characteristics or in cognitive skills. Instead, we show that living in a partnership significantly increases the skill use of men compared with women. We argue that having a partner affects skill use through time allocation as the gender penalty of partnered women is halved once we control for working hours and hours spent on housework. Finally, we do not find evidence of workplace discrimination against women.
\end{abstract}

Keywords Ecomics of gender · Tima allocation and labor supply · Human capital

JEL classification $\mathrm{J} 16 \cdot \mathrm{J} 22 \cdot \mathrm{J} 24$

\section{Introduction}

The gender gap in labor market outcomes has been decreasing rapidly since the World War II (Olivetti and Petrongolo 2016). This positive trend is the result of the decreasing gender segregation across occupations and workplaces. More specifically, the relative position of women in education has increased and, as a consequence, women

\footnotetext{
Responsible editor: Shuaizhang Feng

Balázs Reizer

reizer.balazs@krtk.hu

Rita Pető

peto.rita@krtk.hu

1 Centre for Economic and Regional Studies, Institute of Economics, 1097 4th Tóth Kálmán Street, Budapest, Hungary
} 
are now less likely to be segregated into occupations with low wages and low skill requirements (Reskin 1993; Blau and Kahn 2000). Even so, the pay gap has remained considerably large between women and men with very similar labor market characteristics: Cobb-Clark and Tan (2011) show that the current gender wage differences are much larger within occupations than between occupations.

A strand of recent literature (Spitz-Oener 2006; Autor and Handel 2013; Stinebrickner et al. 2019) uses self-reported skill use measures to investigate the wage differences within occupations. Using the Programme for the International Assessment of Adult Competencies (PIAAC) survey, Christl and Köppl-turyna (2020) showed that women tend to carry out less skill-intensive tasks and consequently earn less than men even within the same "official" occupational category. Black and SpitzOener (2010) found that half of the gender wage convergence between 1980 and 2000 can be attributed to the convergence in executed tasks. Similarly, the convergence in skill use within occupations has halved the part-time wage penalty of women (Elsayed et al. 2017). The differences in skill use have important life cycle effects as well. Stinebrickner et al. (2018) showed that the gender gap increases in early career because women accumulate less experience in using cognitive skills than men. The large within-occupation difference in skill use is surprising as occupations are characterized by a detailed list of tasks and duties as to what individuals should do at their workplace (ISCO International standard classification of occupations 2008).

This paper is the first to investigate directly the possible mechanisms that lead to lower cognitive skill use by women at the workplace. Our most important result is that neither job characteristics nor differences in cognitive test scores can explain the within-occupation gender gap in cognitive skill use. Likewise, a wide set of worker characteristics cannot explain the gender gap. We show that women living in a partnership use their cognitive skills less than men who live with a partner. We argue that the unequal division of housework is an important confounder of the results. The gender penalty of partnered women is halved once we control for working hours and hours spent on housework. Finally, we do not find evidence for workplace discrimination in task allocation and show that differences in preferences cannot explain the gender gap in skill use at work either

As a first step, we document that the tasks performed by women are significantly less skill-intensive on average than those performed by men with the same abilities and in the same occupation. We use the first wave of the PIAAC survey. ${ }^{1}$ This data set is unique in the sense that it contains numeracy and literacy test scores measuring the ability to use cognitive skills as well as detailed information about the actual activities of workers at the workplace (e.g., how often they use a text editor, read directions or instructions, fill in forms). The survey summarizes these activities into standardized indices measuring cognitive and non-cognitive skill use at work. The raw gender gap is around 0.3 standard deviation in numeracy, literacy skill use, and in using information and communication technology skills (ICT skills). The composition effect, including schooling, 3-digit occupational categories, and a wide set of

\footnotetext{
${ }^{1}$ The PIAAC includes 24 countries but we only use 12 countries for which we can match time use data. The results are similar if we include the other countries in the sample.
} 
job characteristics, can explain less than half of the unconditional gender gap in skill use at work. Furthermore, the gender gap in skill use is apparent at every educational level and in every observed country. These differences are significant in economic terms as they correspond to approximately 4 years of schooling. The novelty of our research is that we control for the cognitive test scores of individuals to show that the gender differences in skill use cannot be explained by differences in the ability to use these skills. ${ }^{2}$

In the second part of the paper, we show that having a partner increases skill use among men compared to women with a partner. As a consequence, the gender gap in skill use is much smaller among single workers. We match the time use survey of the International Social Survey Program to the PIAAC data based on demographic characteristics to investigate how hours spent on work at the workplace and housework ${ }^{3}$ contribute to the skill use effect of being in a relationship. We argue that time allocation is an important mechanism through which having a partner affects skill use at work, as the gender penalty of partnered women is halved and becomes insignificant in most of the specifications once we control for working hours and hours spent on housework. Furthermore, we do not find evidence that partnered women use skill less at the workplace because they prefer to use skill less, and we do not find a significant child penalty in skill use at work conditional on hours spent on work at the workplace and at home either.

In the final part of the paper, we discuss the possible mechanisms that may lead to the unequal division of housework. These mechanisms may be lower bargaining power of women, specialization within the household, or social expectations toward the housework of women.

Beyond the literature cited above, our paper also relates to the measurement of workplace tasks. As individual-level skill use measures are rare, the largest strand of literature uses official task descriptions of occupations to measure the activities performed at the workplace. These papers documented decreasing returns to routine tasks and increasing returns to non-routine cognitive tasks (Goos et al. 2009; Acemoglu and Autor 2011; Autor and Dorn 2013). However, without self-reported skill use measures, researchers cannot make inferences on within-occupation differences in skill use. Researchers therefore implicitly assume that differences in skill use within an occupation are random. We add to the previous literature by using selfreported skill use measures to show that women systematically use their cognitive skills less than men wit the same occupation and cognitive test scores.

The paper also relates to the effect of non-cognitive skills on labor market outcomes. Weinberger (2014), Deming (2017), and Deming and Kahn (2018) show that the demand for non-cognitive skills has been increasing over time. Furthermore, Cortes et al. (2018) argue that the increasing demand for social skills has positively affected the college premium among women. We add to this literature by showing that women report lower social skill use than men in the same occupation. Still,

\footnotetext{
${ }^{2}$ Jimeno et al. (2016) show that skill use at the workplace increases cognitive test scores. That is why cognitive test scores over-control for the gender gap in skill use at work.

${ }^{3}$ We observe actual working hours in the PIAAC survey and we only match housework hours.
} 
conditional on total individual skill use, women use non-cognitive skills relatively more intensively.

The paper also contributes to the literature on gender-based discrimination (Wolfers 2006, 5; Goldin 2014b; Miller and Segal 2019). We do not find evidence that less skill-intensive tasks are allocated to women because employers underestimate their cognitive skills (Altonji and Pierret 2001). Recent literature shows that women who are more likely to become pregnant based on their observable characteristics earn less (Yip and Wong 2014; Becker et al. 2019; Jessen et al. 2019). However, we find that age and education-specific birthrates have only a minor effect on skill use at work.

\section{Data and descriptive statistics}

We use the Programme for the International Assessment of Adult Competencies (PIAAC) survey for our analysis. The survey is unique in the sense that it collects information on skill use at the workplace and skill use in leisure time and it contains literacy and numeracy tests to measure skill endowments.

The survey provides a wide set of categorical questions indicating how often respondents do certain activities or use certain tools at their workplace. For each question, workers have to choose one of five categories ranging from "never" to "every day." The OECD summarizes these questions in 9 skill use indices using the generalized partial credit model (GPCM). The GPCM is developed for situations where respondents have to choose from ordered categories. More specifically, the OECD fitted the following model:

$$
\operatorname{Pr}\left(Y_{i j}=1 \mid a_{i}, b_{i}, \theta_{j}\right)=\frac{\exp \left\{a_{i}\left(\theta_{j}-b_{i}\right)\right\}}{1+\exp \left(\left\{a_{i}\left(\theta_{j}-b_{i}\right)\right\}\right.}
$$

where $Y_{i j}$ is 1 if the respondent $j$ chose item $i . \theta_{j}$ is the skill use index for the respondent, while $a_{i}$ and $b_{i}$ are question-specific parameters. The OECD used the PARSCALE software to estimate equation 1 jointly for every question with weighted likelihood estimation. The strengths of the GPCM methodology are discussed by the (OECD 2014) in detail. Most importantly, the skill use index $\theta_{j}$ can be computed even if the respondent does not answer all of the questions regarding the skill use at work. $^{4}$

In this analysis, we focus on the summary indices of basic cognitive skills (numeracy skill use at work, literacy skill use at work, and ICT skill use at work) and examine whether there are any gender differences along these measures. Table 1 summarizes the short definitions of the 9 indices. Appendix Table 10 lists the specific questions which make up the skill use measures. For example, the numeracy skill use measure is constructed from 6 specific questions. Using the GPCM method, the

\footnotetext{
${ }^{4}$ For technical details of the estimation and for the reliability of indices, see Section 20.5 in (OECD 2013).
} 
Table 1 Definition of the main index variables

\begin{tabular}{ll}
\hline Name of index & Definition \\
\hline $\begin{array}{l}\text { In the main analysis: } \\
\text { Numeracy }\end{array}$ & Index of use of numeracy skills \\
& at work (basic or advanced) \\
Writing & Index of use of writing skills at work* \\
Reading & Index of use of reading skills at work* \\
ICT & Index of use of ICT** skills at work \\
In the Appendix: & \\
Influence & \\
Planning & Index of use of influencing skills at work \\
Ready to learn & Index of use of planning skills at work \\
Task discretion & Index of readiness to learn \\
Learning at work & Index of use of task discretion at work \\
\hline
\end{tabular}

*The index of literacy at work combines the indices for reading skills at work and writing skills at work into one measurement using the methodology developed by Anderson (2008)

*** Information and communication technologies

numeracy skill use index can be computed for any respondent who answers at least one of the six questions. We will refer to the indices in the first panel of Table 1 as measures of the skill intensity of a given job.

The second group of questions we use in the paper is the measures of skill use in leisure time. These measures are constructed by the exact same methodology as the skill use at the workplace. A separate set of questions asked the respondents how often they do specific activities in their leisure time. The answers have the same categories, and the same GPCM model summarizes them into indices as in the case of skill use at the workplace. Therefore, the indices on skill use at the workplace and on skill use in leisure time are comparable and have the same scale.

The third group of measures we use is the literacy and numeracy test scores. We use these test scores as the proxy of the cognitive skill endowment of the respondents. ${ }^{5}$ According to the (OECD 2012) definition, the tests related to literacy are developed in a way so as to measure "understanding, evaluating, using, and engaging with written texts to participate in society, to achieve one's goals, and to develop one's knowledge and potential" ((OECD 2012), p. 20). Similarly, the numeracy skill tests are aimed at measuring "the ability to access, use, interpret, and communicate mathematical information and ideas, to engage in and manage mathematical demands of a range of situations in adult life" ((OECD 2012), p. 33). Hereafter, we use these tests

\footnotetext{
${ }^{5}$ The survey provides ICT skill measures only for a small subsample and does not measure non-cognitive skills. Thus, we cannot include these measures into the analysis.
} 
Table 2 Sample size by country and gender

\begin{tabular}{llll}
\hline Country & Men & Women & Total \\
\hline Czech Republic & 1131 & 1423 & 2554 \\
Denmark & 1913 & 1863 & 3776 \\
France & 1507 & 1605 & 3112 \\
Great Britain & 1553 & 2424 & 3977 \\
Germany & 1290 & 1481 & 2771 \\
Japan & 1506 & 1396 & 2902 \\
Korea & 1583 & 1432 & 3015 \\
Norway & 1255 & 1423 & 2678 \\
Poland & 1412 & 1622 & 3034 \\
Russian Federation & 415 & 1083 & 1498 \\
Slovakia & 1046 & 1242 & 2288 \\
Spain & 1090 & 1105 & 2195 \\
Total & 15,701 & 18,099 & 33,800 \\
\hline
\end{tabular}

as proxies for cognitive skills. The survey also provides information on the respondents' labor market status, education, social background, occupation (3-digit ISCO codes), etc.

The study was conducted in 2011-2012 by interviewing about 5000 individuals (aged 16-65) in each of the participating countries. In our analysis, we are focusing on 12 countries where we can link the PIAAC data to the time use information. ${ }^{6}$ Altogether, we observe a sample of 33,800 working individuals for whom at least one of the cognitive skill use indices is available (see Table 2), 53,5\% of which are women. We use the sampling weights provided by the OECD throughout the analysis.

Table 3 provides basic descriptive statistics for males and females. To facilitate comparison, we also provide the estimated differences across gender and the t-statistics. We use the sampling weights provided by the data set and we use the full sample. ${ }^{7}$ Male workers are somewhat more experienced and they are more likely to have full-time jobs. As a consequence, men work $7.41 \mathrm{~h}$ more on average than women. Women are less likely to work at private firms, while men and women are equally likely to have children. Women perform worse on the cognitive tests (numeracy and literacy tests) and they use their cognitive skills less at work as well.

To better understand the selection into employment, the same descriptive statistics (where it was relevant) are calculated for unemployed people (see Appendix Table 11). In line with our intuition, unemployed people are less experienced and are less educated than the employed. Unemployed women perform worse on cognitive tests related to numeracy skills, while they outperform unemployed men on literacy tests.

\footnotetext{
${ }^{6}$ In Section 3, we also investigate the gender gap by country.

${ }^{7}$ The results are virtually the same for the sub-sample where all measures of the skill intensity of the job are available.
} 
Table 3 Descriptive statistics for the main variables

\begin{tabular}{|c|c|c|c|c|}
\hline Variable & Male & Female & Difference & $t$-stat \\
\hline Experience (year) & $\begin{array}{l}19.43 \\
(0.16)\end{array}$ & $\begin{array}{l}17.07 \\
(0.14)\end{array}$ & -2.36 & -11.20 \\
\hline Years of education & $\begin{array}{l}13.99 \\
(0.04)\end{array}$ & $\begin{array}{l}13.76 \\
(0.04)\end{array}$ & -0.23 & -4.13 \\
\hline Share of full time workers & $\begin{array}{c}0.88 \\
(0.00)\end{array}$ & $\begin{array}{r}0.67 \\
(0.01)\end{array}$ & -0.21 & -29.75 \\
\hline Weekly work hours & $\begin{array}{l}43.45 \\
(0.17)\end{array}$ & $\begin{array}{l}36.04 \\
(0.15)\end{array}$ & -7.41 & -31.98 \\
\hline Share of those who have children under age 18 & $\begin{array}{c}0.14 \\
(0.01)\end{array}$ & $\begin{array}{r}0.13 \\
(0.00)\end{array}$ & -0.01 & -0.93 \\
\hline Native & $\begin{array}{c}0.87 \\
(0.00)\end{array}$ & $\begin{array}{r}0.87 \\
(0.00)\end{array}$ & 0.00 & 0.24 \\
\hline Employed in private sector & $\begin{array}{c}0.79 \\
(0.01)\end{array}$ & $\begin{array}{c}0.68 \\
(0.01)\end{array}$ & -0.11 & -13.24 \\
\hline Average numeracy test score* & $\begin{array}{c}0.15 \\
(0.01)\end{array}$ & $\begin{array}{r}-0.15 \\
(0.02)\end{array}$ & -0.30 & -13.91 \\
\hline Average literacy test score* & $\begin{array}{c}0.06 \\
(0.01)\end{array}$ & $\begin{array}{r}-0.06 \\
(0.02)\end{array}$ & -0.12 & -6.09 \\
\hline Numeracy skill use at work** & $\begin{array}{c}0.15 \\
(0.01)\end{array}$ & $\begin{array}{r}-0.15 \\
(0.01)\end{array}$ & -0.29 & -15.34 \\
\hline Literacy skill use at work** & $\begin{array}{c}0.15 \\
(0.01)\end{array}$ & $\begin{array}{r}-0.15 \\
(0.01)\end{array}$ & -0.30 & -15.49 \\
\hline ICT skill use at work** & $\begin{array}{c}0.13 \\
(0.01)\end{array}$ & $\begin{array}{c}-0.14 \\
(0,01)\end{array}$ & -0.28 & -13.84 \\
\hline Observations & 15,701 & 18,099 & & \\
\hline
\end{tabular}

\footnotetext{
* Standardized test score with a mean of 0 and a variance of 1

${ }^{* *}$ Standardized skill use indices with a mean of 0 and a variance of 1
}

The information on housework and family care comes from the fourth wave of the International Social Survey Programme: Family and Changing Gender Roles (ISSP). The survey was conducted in 2012 and aims at measuring attitudes toward marriage, child bearing and activities pursued in leisure time and at the workplace (ISSP, (ISSP International social survey programme 2019)). The database contains selfreported information on the hours spent on housework and family care separately. ${ }^{8}$ As a first step, we calculate average housework and family care by country of origin,

\footnotetext{
${ }^{8}$ The ISSP survey asks "On average, how many hours a week do you personally spend on household work, not including childcare and leisure time activities?" and "On average, how many hours a week do you spend looking after family members (e.g., children, elderly, ill, or disabled family members)?"
} 
gender, marital status, 1-digit occupational category, educational level, and a children dummy. We choose these dimensions to maximize the relevant categories and the share of respondents to whom we can match housework information at the same time. Next, we use exact matching based on these demographic characteristics to match the segment-level average hours spent on housework from the ISSP with the individual observations in the PIAAC data. ${ }^{9}$ These categorical variables define 1476 distinct segments, which we observe both in the ISSP and the PIAAC. These segments consist of 33,800 respondents, who are shown in Table 2. There are 454 segments and 2668 respondents in the PIAAC survey to whom we cannot match housework information.

Using segment-level averages as a proxy for individual housework has two important features. First, these measures of household activities are not correlated with unobserved individual characteristics, which are correlated both with individual hours spent on housework and skill use at work. Therefore, the results can be interpreted as the estimate of the reduced form of an instrumental variables model where the instrument of individual housework is the leave-out-mean of the group (Townsend and et al. 1994).

Second, the group-level average measures individual hours spent on housework and family care with a random measurement error which biases the parameters of these variables toward zero (attenuation bias). To better understand the problem, let $x_{i}$ denote the housework done by worker $i$ in segment $s$. Without loss of generality, we can assume that $x_{i}=x_{s}+\epsilon_{i}$ where $x_{s}$ is the expected value of housework in the segment and $\epsilon_{i}$ is a zero mean random term. Instead of observing $x_{i}$, we only observe the average housework of individuals in segment $s$ in the ISSP survey $\left(\bar{x}_{i}\right)$. In this setup, there are two types of measurement error. First, we do not observe $\epsilon_{i}$. Second, the group average $\bar{x}_{i}$ is only a noisy measure of $x_{s}$. The attenuation bias caused by the measurement error is decreasing in the variance of $\bar{x}_{i}$ (Wooldridge 2010). By the law of large numbers, this variance is larger if the size of the segment is smaller in the ISSP. On the one hand, the estimation is possible even if we observe only one individual in each segment in the ISSP survey. On the other hand, despite the attenuation bias, our estimated parameters are significant (Section 3.1, Table 7). Besides, the attenuation bias also implies that we underestimate the effect of housework on skill use at work and overestimate the conditional gender gap in absolute terms (Bollinger 2003). The same argument applies for using group-level averages as a proxy for individual hours spent on family care. As a result, our estimates give an upper bound in absolute terms for the gender gap in skill use at work.

Figure 1 panel A shows the distribution of weekly housework in the combined database. According to the figure, the hours spent on housework vary significantly across individuals and we also find important gender differences in this regard. On average, women devote 7.2 more hours to housework than men and they are significantly less likely to report fewer than $10 \mathrm{~h}$. Compared to housework hours, we can

\footnotetext{
${ }^{9}$ The segments represents 9425 individuals in the ISSP, which means that the segments contain 6.4 individuals on average. The between-group variation of housework hours covers more than $60 \%$ of the total variance in household hours (the total standard deviation of housework is $10.5 \mathrm{~h}$, while the betweensegment variation is $6.6 \mathrm{~h}$ ). The information loss is less in the case of family care, where the total standard deviation is 12.6 , while the between-group variation is $10 \mathrm{~h}$.
} 

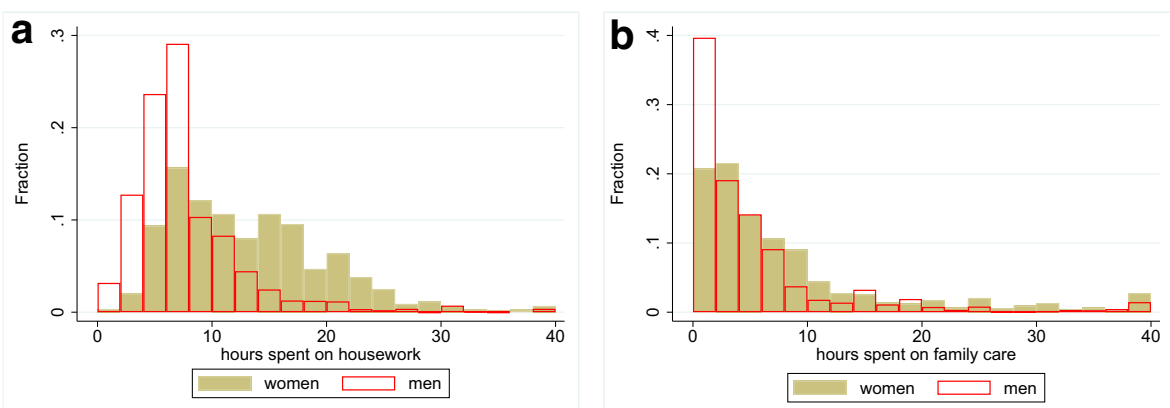

Fig. 1 Distribution of weekly housework and family care by gender (hours). The number of hours spent on housework and family care is winsorized at $40 \mathrm{~h}$. a Panel A: Distribution of hours spent on housework. b Panel B: Distribution of hours spent on family care

observe a much smaller gender difference in the hours spent on family care. Although men are more likely to report very low hours spent on family care, on average, women spend only $3.2 \mathrm{~h}$ more on family care than men.

We can also test the reliability of the results by comparing the self-reported and spouse-reported hours spent on housework. The ISSP survey includes only one member of the household and the respondent has to gauge the amount of her own and her spouse's housework. If people systematically overestimate their own housework, then we expect that self-reported housework hours is higher than spouse-reported housework hours. ${ }^{10}$ In contrast, Appendix Fig. 2 highlights that the distribution of housework remarkably overlaps for both men and women. That is why we conclude that the number of self-reported hours spent on housework is indeed an unbiased measure of the activities at home.

Table 4 summarizes the hours spent on housework by gender and partnership status. The most apparent difference is that women spend more time on housework than men, independently of their partnership status. Not surprisingly, single men without children spend the least amount of time on housework (6.77 h a week), $2.14 \mathrm{~h}$ less than single women without children. Furthermore, the table shows ample evidence of the unequal division of housework between the partners. Women without children living in a partnership spend $3.25 \mathrm{~h}$ more on housework weekly than single women without children, while men living in a partnership spend only $0.56 \mathrm{~h}$ more on housework than their single counterparts. We see a striking difference among women with children. If partnered women have children, they spend $5.06 \mathrm{~h}$ more on housework than partnered women without children. Altogether, women living with a partner spend almost twice as many hours on housework than men.

As opposed to this, we do not find such a large gender difference in hours spent on family care. ${ }^{11}$ Living with a partner increases the hours spent on family care for

\footnotetext{
${ }^{10}$ This may be especially problematic among women, who may over-report their housework because of social expectations.

${ }^{11}$ Note: The ISSP survey does not specify whether family care is related to children, old parents, or other family members.
} 
Table 4 Hours spent on housework by gender

\begin{tabular}{|c|c|c|c|c|}
\hline & \multicolumn{2}{|l|}{ Single } & \multicolumn{2}{|l|}{ With partner } \\
\hline & No children & Children & No children & Children \\
\hline \multicolumn{5}{|l|}{ Panel A: Men } \\
\hline Hours spent on housework & $\begin{array}{r}6.77 \\
(4.66)\end{array}$ & $\begin{array}{c}7.30 \\
(4.43)\end{array}$ & $\begin{array}{c}7.33 \\
(4.76)\end{array}$ & $\begin{array}{c}7.55 \\
(5.93)\end{array}$ \\
\hline Hours spent on family care & $\begin{array}{r}3.09 \\
(4.50)\end{array}$ & $\begin{array}{c}4.80 \\
(8.17)\end{array}$ & $\begin{array}{c}4.11 \\
(6.20)\end{array}$ & $\begin{array}{c}6.59 \\
(8.52)\end{array}$ \\
\hline Observations & 4653 & 1797 & 1023 & 9349 \\
\hline \multicolumn{5}{|l|}{ Panel B: Women } \\
\hline Hours spent on housework & $\begin{array}{c}8.91 \\
(5.62)\end{array}$ & $\begin{array}{l}15.21 \\
(6.71)\end{array}$ & $\begin{array}{c}12.16 \\
(6.89)\end{array}$ & $\begin{array}{l}17.22 \\
(7.11)\end{array}$ \\
\hline Hours spent on family care & $\begin{array}{c}3.84 \\
(4.06)\end{array}$ & $\begin{array}{c}6.42 \\
(5.60)\end{array}$ & $\begin{array}{c}7.46 \\
(9.31)\end{array}$ & $\begin{array}{c}10.94 \\
(10.06)\end{array}$ \\
\hline Observations & 4407 & 212 & 2922 & 10482 \\
\hline
\end{tabular}

men and women alike. Similarly, people having children spend more on family care than people without children.

Finally, if housework hours depended only on the division of housework within households, single men and single women with children would allocate a similar number of hours to housework. To the contrary, we find that single women with children spend $15.21 \mathrm{~h}$ per week on housework, while single men with children spend only $7.30 \mathrm{~h}$ on housework. This difference cannot be explained by the unequal division of housework; other mechanisms may also play a role.

Finally, we plot the average hours spent on family care as the function of hours spent on housework. By doing so, we test whether people responsible for an especially large amount of housework can devolve family care to other adults in the family/household. The working paper versions ((Pető and Reizer 2021) show groups the people into 20 equally sized bins by the amount of reported housework and plots the average hours spent on family care for men and women. The figure highlights that women spend more time on family care at every level of housework and people who report larger amounts of housework also spend more time on family care. Based on these facts, we conclude that there is no trade-off between doing more housework and spending more time on family care.

\section{Results}

This section shows that women use their cognitive skills at the workplace less often than men but the heterogeneity in individual and job characteristics cannot, in itself, explain this gender gap. To prove this claim, we run Mincerian-type regressions 
where the left hand side variable is one of the indices measuring the skill intensity of the job (see Table 1). We pool all countries in our sample together. Our main right hand side variable is gender, while controlling for different sets of variables:

$$
y_{i}=\alpha+\beta * \text { female }_{i}+X_{i} \gamma+u_{i},
$$

where $y_{i}$ denotes the examined skill intensity measure (standardized to have a mean of zero and a standard deviation of one). The main coefficient of interest is $\beta$ showing the gender gap in skill use at the workplace. $X_{i}$ is the set of control variables including the numeracy and literacy test scores of the respondents. The test scores enable us to show that women do not use their cognitive skills less because of their lack of skills. ${ }^{12}$ Besides controlling for individual skills, we also mimic a Mincerian-type wage equation by controlling for years of education, experience, experience-square, occupation (3-digit ISCO codes), etc. ${ }^{13}$ As occupations are defined by a detailed list of tasks and duties that employees have to fulfill at their workplace, the occupation categories alone should explain the individual heterogeneity in skill use at work. By including occupational categories and cognitive test scores in the control variables, we do not only control for the tasks that employees should carry out at work but also for the individual's ability to use cognitive skills. Finally, workers' tasks may differ county by country even if they have the same occupational category. That is why we use country-occupation fixed effects instead of occupational fixed effects to account for these differences.

As an additional robustness check, we use propensity score matching to ensure that only observationally similar men and women are used for the estimation. We follow the strategy of Hampf and Woessmann (2017). First, we estimate the propensity scores by using a logit model, we include in the model the age, years of education, literacy, and numeracy test scores. Second, with the estimated propensity scores in hand, we use the nearest-neighbor matching by country. Which means that we matched without replacement every woman with the man of the same country with the closest propensity score. This procedure ensures that gender difference in skill use at work is estimated on common support at the cost of losing $22 \%$ of the sample. As the choice of the confounders is arbitrary, we made sensitivity test by using different set of control variables. The estimates are very similar to the results in the main text (see in the working paper version (Petô and Reizer 2021)).

The point estimates for Eq. 2 are shown in Table 5. The three skill use indices are shown in separate panels while the columns differ in control variables. According to column (1), women use their cognitive skills with an approximately 0.3 standard

\footnotetext{
${ }^{12}$ If cognitive and non-cognitive skills are correlated and we do not control for non-cognitive skill endowment, then the parameters of the test scores are biased. The PIAAC data do not measure non-cognitive skill endowment and that is why we proxy it with trust in other individuals The correlation between our cognitive and non-cognitive skill measures is positive but low (the correlation between trust and literacy test scores is 0.1254 , while it is 0.1443 for trust and numeracy test scores). Still, if men and women have the same average cognitive and non-cognitive skill endowments conditional on test scores and trust, then Eq. 2 gives an unbiased estimate of the gender gap in skill use at work (Heckman et al. 2018).

${ }^{13}$ The remaining control variables are parents' highest level of education, trust in other people, dummy for those managing others, self-employment dummy, dummy for those having a permanent contract, having a partner, dummies for 1-digit industry, 5 firm size categories, and private sector control.
} 
Table 5 Gender gap in skill use at work
(1)
(2)
(3)
(4)
PS matching

Panel A: Numeracy skill use at work

$\begin{array}{lllll}\text { Female } & -0.302 * * * & -0.225^{* * *} & -0.159 * * * & -0.132 * * * \\ \text { Years of education } & (0.016) & (0.018) & (0.018) & (0.018) \\ & & & 0.023^{* * *} & 0.029^{* * *} \\ \text { Literacy test scores } & & (0.004) & (0.004) \\ & & -0.011 & 0.000 \\ \text { Numeracy test scores } & & (0.023) & (0.022) \\ & & 0.133^{* * *} & 0.120^{* * *} \\ \text { Observations } & & & (0.023) & (0.022) \\ R \text {-squared } & 30,263 & 30,263 & 30,263 & 23,826 \\ & 0.030 & 0.280 & 0.320 & 0.320\end{array}$

Panel B: Literacy skill use at work

$\begin{array}{lllll}\text { Gender gap } & -0.267 * * * & -0.234^{* * *} & -0.180^{* * *} & -0.166^{* * *} \\ & (0.016) & (0.016) & (0.017) & (0.018) \\ \text { Years of education } & & & 0.042^{* * * *} & 0.043^{* * *} \\ \text { Literacy test scores } & & (0.005) & (0.005) \\ & & 0.002 & 0.015 \\ \text { Numeracy test scores } & & (0.018) & (0.020) \\ & & 0.010 & -0.014 \\ \text { Observations } & & & (0.018) & (0.021) \\ R \text {-squared } & 31,278 & 31,278 & 31,278 & 24,508 \\ & 0.047 & 0.329 & 0.370 & 0.375\end{array}$

Panel C: ICT skill use at work

\begin{tabular}{|c|c|c|c|c|}
\hline Gender gap & $\begin{array}{l}-0.293^{* * *} \\
(0.017)\end{array}$ & $\begin{array}{l}-0.176^{* * *} \\
(0.018)\end{array}$ & $\begin{array}{l}-0.140^{* * *} \\
(0.017)\end{array}$ & $\begin{array}{l}-0.119^{* * *} \\
(0.019)\end{array}$ \\
\hline Years of education & & & $\begin{array}{l}0.037 * * * \\
(0.005)\end{array}$ & $\begin{array}{l}0.041 * * * \\
(0.006)\end{array}$ \\
\hline Literacy test scores & & & $\begin{array}{l}0.034 \\
(0.025)\end{array}$ & $\begin{array}{l}0.041 \\
(0.027)\end{array}$ \\
\hline Numeracy test scores & & & $\begin{array}{l}-0.002 \\
(0.024)\end{array}$ & $\begin{array}{l}-0.015 \\
(0.027)\end{array}$ \\
\hline
\end{tabular}


Table 5 (continued)

(1)

(2)

(3)

4)

PS matching

\begin{tabular}{lllll}
\hline Observations & 25,931 & 25,931 & 25,931 & 20,155 \\
$R$-squared & 0.048 & 0.298 & 0.338 & 0.348 \\
Country fixed effects & Yes & Yes & Yes & Yes \\
Country-occup. fixed effects & No & Yes & Yes & Yes \\
Controls & No & No & Yes & Yes \\
\hline
\end{tabular}

Standard errors are in parentheses $* * * p<0.01, * * p<0.05, * p<0.1$. Control variables differ by column. Column (1) controls for country fixed effects. Column (2) controls for country-occupation fixed effects. Column (3) also controls for years of education and standardized literacy and numeracy test scores, partner dummy, experience, experience ^2, parents’ highest level of education, self-employment dummy, dummy for having a permanent contract, dummies for 1-digit industry, 5 firm size categories, private sector, dummy for those managing others, and trust in others. Column (4) shows the results estimated on the matched sample that uses propensity score matching (see the text for the details). Standard errors are calculated with the jackknife method (suggested by OECD (2013)) using 80 replication weights. All of the results are calculated by using sampling weights provided by the survey.

deviation less than men. The raw differences are somewhat larger in numeracy skill use (coef. 0.302, s.e. 0.016) and lower in literacy and ICT skill use.

We add country-occupation fixed effects in column (2) to show that women use their cognitive skills less than men of the same occupations. Panel A in column (2) shows that women use their numeracy skills with 0.225 standard deviation less than men working in the same country and occupation. The within-occupation difference is somewhat larger in literacy skill use (0.234 standard deviation) and lower in the ICT skill use (0.176 standard deviation). The results imply that two-thirds of the raw gender gap is within occupation. This is a surprising result as occupations are defined by the list of tasks which the worker should carry out at their workplace.

Column (3) incorporates the full set of individual and job characteristics including literacy and numeracy test scores. The other control variables are education, experience, square of experience, dummies for 1-digit industry codes, 5 firm size categories, and a wide set of information on family background. According to the results, these variables cannot explain the gender gap in skill use either since half of the raw gender gap remains unexplained. Investigating the coefficient of education reveals that the gender gap in skill use has a large magnitude. Workers with one more year of education use their cognitive skills with 0.02-0.04 standard deviation (s.e. $0.005)$ more. These results indicate that conditional on occupation, 1 year of additional schooling corresponds to a much smaller increase in cognitive skill use than the gender gap. ${ }^{14}$ Finally, column (4) uses propensity score matching to ensure that

\footnotetext{
${ }^{14}$ This specification over-controls for the effect of education as many occupations with high cognitive skill use have explicit educational requirements (e.g., teachers, doctors) and education raises cognitive test scores as well.
} 
we compare similar men and women. Even though the sample size drops, the point estimates do not change significantly compared to column (3). ${ }^{15}$

Robustness checks In Table 5, we implicitly assumed that skill use indices are uncorrelated with each other. We test the robustness of this assumption in Appendix Table 12. More precisely, we estimate the gender gap in skill for the three skill use indices together using seemingly unrelated regression (SUR). The strength of the SUR model is that it enables correlation between the skill use indices but we can use only those respondents for the estimation who have all three skill use indices. In panel A, we control for country fixed effects, while in panel B, we use all of the control variables (as in Table 5, column (3)). Reassuringly, both the point estimates and the standard errors are similar to the results in Table 5.

As an alternative method to deal with the correlation between skill use indices, we use the method of Lavy et al. (2016). This method summarizes the differences in the three skill use indices into one measure with the appropriate standard errors. Again, the results are shown to be similar to previous results (column (4)).

The GPCM method used for the computation of skill use indices has strict functional form assumptions. To investigate the robustness of these assumptions, we estimate the gender gap in skill use by specific activities. As the possible answers have an ordered scale, we use ordered logit regression for the analysis. As expected based on the skill use indices, women do most of the activities less often than men. Nevertheless, women use calculators more often than men and there are some activities where there is no gender gap, e.g., writing memos or emails, or using a word processor. The results are available upon request.

Heterogeneity of the gender gap by groups We also investigate whether the gender gap in skill use differs by groups. First, we estimate the skill use by country. The working paper version (Petô and Reizer 2021) shows that there is significant heterogeneity across countries. We observe the largest gender gap in skill use in Japan, where gender inequality is traditionally large. Surprisingly, the gender gap in skill use is also very large in Scandinavian countries (Denmark and Norway), which are considered some of the most gender-equal societies. In contrast, we find the smallest gender gap in skill use at work in the post-communist countries (Poland, Russia, Slovakia). These countries have the lowest gender gap in numeracy and literacy skill use but an above-average gender gap in ICT skill use.

Appendix Fig. 3 plots the gender gap in skill use by educational categories. This exercise is motivated by previous research showing large heterogeneity in gender wage gap by educational level (Dela Rica et al. 2008). We find a significant gender gap in every educational category. Women with secondary education experience the largest penalty in numeracy and literacy skill use compared to men of the same

\footnotetext{
${ }^{15}$ Even though the regression in Table 5 does not make use of the housework information, we only included the sub-sample of respondents in the PIAAC survey to whom we could match housework information. The results do not change if we include those individuals to whom we can not match housework information. (see in the working paper version (Petô and Reizer 2021).
} 
educational level. This difference remains significant even if we control for occupation, cognitive test scores, working hours, and other control variables. Furthermore, women with professional degrees suffer the largest penalty in ICT skill use, but the gap decreases once we control for worker composition.

We do not find large heterogeneity across broad occupational categories either. The working paper version (Petô and Reizer 2021) shows that the gender gap is of a similar magnitude in all broad occupational categories. ${ }^{16}$ The only notable exceptions are service jobs where the gender gap is larger than average in all of the skill use measures.

Finally, we investigate the gender gap in skill use by firm size. The working paper version (Petô and Reizer 2021) shows that the unconditional gender gap in skill use is apparent at every firm size but is somewhat smaller at the largest firms. This negative relationship is robust to introducing controls for individual characteristics (e.g., occupation and cognitive skills, working hours) and it is the most apparent in ICT skills.

Gender differences in cognitive skills and the skill requirement of jobs It is possible that women use their cognitive skills less than men because women have relatively lower cognitive test scores in occupations with high cognitive skill requirements (thus a large gender gap in actual skill use). Furthermore, if women may have better cognitive test scores than men in occupations with very low skill requirements (thus with a small gender gap in actual skill use), then the cognitive test scores and the gender gap in skill use would be uncorrelated in the whole sample (as found in the data) but negatively correlated across occupations. To rule out this scenario (Petố and Reizer 2021), plots the average skill use at work by the gender gap in skill use. We find that women have higher cognitive test scores than men in occupations with high literacy skill use, but the gender gap in cognitive test scores is uncorrelated with numeracy and ICT skill use. Based on these facts, we conclude that the gender gap in skill use cannot be explained by the lack of cognitive skills in highly skill-intensive occupations.

Non-cognitve skill use at work Women on average have better non-cognitive skills than men (Jacob 2002); that is why women may specialize in tasks which need higher non-cognitive skill use and lower cognitive skill use than the tasks fulfilled by men. If this was the main reason for the gender gap in cognitive skill use, we would expect that women report higher non-cognitive skill use than men.

To test this hypothesis, we estimate the gender difference in non-cognitive skill use. The PIAAC survey has four indices measuring non-cognitive skill use, including the planning and influencing skill use at the workplace. We re-estimate Eq. 2 using these variables in Appendix Table 13. Column (1) in panel B shows that women use influencing skills with 0.246 standard deviation less than men. Furthermore, the gap does not disappear once we control for a wide set of other control variables (columns (2)-(3)) or if we compare only observationally similar males and females (column (4)). Finally, panel A, panel C, and panel D show that women also use their planning

\footnotetext{
${ }^{16}$ The categories are based on 1-digit ISCO codes.
} 
and learning skills less often and also have lower task discretion. The results remain qualitatively the same if we use seemingly unrelated regressions and the observations only where all of the non-cognitive skill use indices are available (Appendix Table 14). As women use non-cognitive skills less often than men, we conclude that specialization in non-cognitive skill use cannot explain the lower gender gap in cognitive skill use.

Finally, if women use their cognitive skills less only because they specialize in non-cognitive skill use, then we expect a larger gender gap in cognitive skill use in occupations with the highest non-cognitive skill requirements. That is why we estimate the relationship between the non-cognitive skill requirements of occupations and the within-occupation gender gap in cognitive skill use. We use the importance of cooperation in the given occupation as a proxy for the non-cognitive skill requirements of that occupation. ${ }^{17}$ Appendix Fig. 4 orders the 3-digit occupations by the importance of cooperation and plots the gender gap in cognitive skill use in every occupation. The figure highlights that there is no significant relationship between the cooperation skill requirements of the occupation and the gender gap in cognitive skill use. This result also suggests that women do not report lower cognitive skill use than men because they over-estimate the importance of non-cognitive skill use.

Even though women report lower non-cognitive skill use than men, women may use non-cognitive skills more intensively conditional on total (gender-specific) skill use at work. We can test this possibility by comparing Appendix Table 12 column (4) and Appendix Table 14 column (5). These two columns measure the gender gap in cognitive and non-cognitve skill use with the same method (Lavy et al. 2016) and on the same scale (standardized to have mean of zero and standard deviation of one). According to the results, the conditional gender gap is 0.175 standard deviation in cognitive skill use and 0.077 standard deviation in non-cognitive skill use. These results mean that women indeed use non-cognitive skills relatively more intensively conditional on total skill use.

\subsection{The effect of partnership and time allocation on the gender gap in skill use}

In the previous section, we showed that the gender gap in skill use cannot be explained by education, occupation, or by differences in literacy and numeracy test scores. In this section, we investigate how partnership and gender differences in working hours, hours spent on housework, and family care contribute to the gender gap in skill use. This exercise is motivated by previous studies showing that household activities (Hersch and Stratton 2002; Cubas et al. 2019) and working hours (Goldin 2014a) are key drivers of the gender pay gap.

Table 6 shows the effect of living with a partner on the gender gap in skill use at work conditional on having a partner. Here, the female dummy shows the gender gap in skill use among single households. The "has a partner dummy" shows the skill use gap between men with and without a partner, while the interaction term shows

\footnotetext{
${ }^{17}$ We use the standardized importance of cooperation measure of O*NET (2018) and the crosswalk of Hardy et al. (2018) to link the O*NET occupational categories to the 3-digit ISCO-08 codes.
} 
the difference in the gender gap in skill use between partnered individuals and single individuals.

Column (1) of panel A highlights that women without a partner use their numeracy skills with 0.170 (s.e. 0.029) standard deviation less than single men. Thus, the raw gender gap in numeracy skill use is significantly smaller among people without a partner than in the whole sample (Table 5, column (1)). Furthermore, we do not find significant gender difference in ICT skill use among single individuals conditional on observable characteristics. The parameter of the partner dummy shows that men having a partner use their cognitive skills with 0.195 (s.e. 0.023 ) standard deviation more than men without a partner. The negative parameter of the interaction term means that the raw gender gap among partnered individuals is with 0.189 standard deviation (s.e. 0.031) larger than among single individuals. Finally, women having a partner use their numeracy skills with $0.195-0.189=0.006$ standard deviation more than single women. This difference is not significant either in economic or statistical sense. Turning to literacy and ICT skill use, we see similar patterns but the effect of having a partner on women's skill use is much larger. According to these results, men having a partner use their cognitive skills more at the workplace than single men, but we do not observe such a difference among women.

The effect of having a partner decreases if we control for gender differences in occupation (column (2)), or add a wide set of control variables including test scores (column (3)). Still, the results are qualitatively the same, the gender gap in skill use is much lower among single individuals. What is more, we do not find a significant difference among single men and women in ICT skill use if we control for differences in observable characteristics. Similarly, it is only men with partners and not women with partners that use their cognitive skills more than their single counterparts.

The division of housework between partners can be a crucial channel through which partnerships affect labor market outcomes. That is why we re-estimate Table 6 conditional on the actual hours worked at the workplace and segment-level average hours spent on housework and family care.

Column (1) in Table 7 shows that one additional hour worked at the workplace increases numeracy skill use with 0.012 standard deviation while spending one additional hour housework is associated with a 0.016 standard deviation decrease in numeracy skill use at work. The effect is even larger in case of literacy skill use ( -0.024 standard deviation) and ICT skill use ( -0.019 standard deviation). The coefficients are somewhat smaller once we control for country-occupation fixed effects (column (2)), or include a wide set of job characteristics in column (3). The results are also robust to restricting the sample only to observationally comparable men and women (column (4)). In contrast, the hours spent on family care have a much lower effect on skill use at the workplace. What is more, the parameters of family care are significantly positive in some specifications.

Turning to the gender gap in skill use, the gender penalty of having a partner decreases compared to Table 6, once we control for time allocation individual. The interaction of female and partnership is not significant in the case of numeracy skill use and literacy skill use and halves in the case of ICT skill use at work (see column 3). The reason for the drop in the gender penalty compared to Table 6 is that partnered women do much more housework than partnered men (see Table 4) and there is a 
Table 6 The effect of partnership on the gender gap

(1) (2)

(3)

(4)

PS matching

Panel A: Numeracy skill use at work

Female

Has a partner

Partner*female

Observations

$R$-squared

$$
\begin{aligned}
& -0.170^{* * *} \\
& (0.029)
\end{aligned}
$$

$0.195 * * *$

(0.023)

$-0.189 * * *$

(0.031)

29,938

0.035

Panel B: Literacy skill use at work

Female

Has a partner

Partner*female

Observations

$R$-squared

Panel C: ICT skill use at work

Female

Has a partner

Partner*female

Observations

$R$-squared

Country fixed effects

Country-occup. fixed effects

Other for job characteristics

$$
-0.040
$$

$0.315^{* * *}$

(0.030)

$-0.309^{* * * *}$

(0.041)

30,955

0.055

$-0.133 * * *$
$(0.032)$

$0.223 * * *$

(0.033)

$-0.221 * * *$

$(0.039)$

25,701

0.054

Yes

No

No

$$
\begin{aligned}
& -0.061^{* *} \\
& (0.029)
\end{aligned}
$$

$-0.136^{* * *}$
$(0.025)$

$0.120^{* * * *}$

(0.021)

$-0.123 * * *$

(0.028)

29,938

0.283

$-0.122 * * *$
$(0.025)$

$0.157^{* * *}$

(0.026)

$-0.157 * * *$

(0.035)

30,955

0.332

$0.148^{* * *}$

(0.028)

$-0.168 * * *$

(0.035)

25,701

0.304

Yes

Yes

No

$-0.089 * * *$
$(0.026)$

$-0.077^{* *}$

(0.030)

$0.077^{* * *}$

(0.027)

(0.023)

$-0.096 * * *$

$-0.076^{* *}$

(0.028)

(0.032)

29,938

23,604

0.322

0.322

$-0.101 * * *$

(0.031)

$0.081^{* *}$

(0.034)

$-0.095^{* *}$

(0.039)

24,288

0.381

Standard errors are in parentheses $* * * p<0.01, * * p<0.05, * p<0.1$. Control variables differ by column. Column (1) controls for country fixed effects. Column (2) controls for country-occupation fixed effects. Column (3) also controls for years of education and standardized literacy and numeracy test scores, partner dummy, experience, experience`2, parents' highest level of education, self-employment dummy, dummy for having a permanent contract, dummies for 1-digit industry, 5 firm size categories, private sector, dummy for those managing others, and trust in others. Column (4) shows the results estimated on the matched sample that uses propensity score matching (see the text for the details). Standard errors are calculated with the jackknife method (suggested by OECD (2013)) using 80 replication weights. All of the results are calculated by using sampling weights provided by the survey 
Table 7 The effect of time allocation on the gender gap

\begin{tabular}{lllll}
\hline & $(1)$ & $(2)$ & $(3)$ & $\begin{array}{l}(4) \\
\text { PS matching }\end{array}$ \\
\hline Panel A: Numeracy skill use at work & & & \\
Female & $-0.098^{* * * *}$ & $-0.111^{* * *}$ & $-0.071^{* * *}$ & $-0.059^{* *}$ \\
& $(0.028)$ & $(0.024)$ & $(0.025)$ & $(0.030)$ \\
Has a partner & $0.150^{* * *}$ & $0.090^{* * *}$ & $0.074^{* * *}$ & $0.065^{* *}$ \\
& $(0.023)$ & $(0.022)$ & $(0.024)$ & $(0.028)$ \\
Partner*female & -0.030 & -0.055 & -0.052 & -0.024 \\
& $(0.042)$ & $(0.037)$ & $(0.036)$ & $(0.036)$ \\
Hours worked & $0.012^{* * *}$ & $0.010^{* * *}$ & $0.008^{* * *}$ & $0.009 * * *$ \\
& $(0.001)$ & $(0.001)$ & $(0.001)$ & $(0.001)$ \\
Hours spent on housework & $-0.016^{* * * *}$ & -0.004 & -0.002 & -0.002 \\
& $(0.002)$ & $(0.002)$ & $(0.002)$ & $(0.003)$ \\
Hours spent on family care & $0.003^{* * *}$ & $0.002^{* * *}$ & 0.001 & 0.001 \\
& $(0.001)$ & $(0.001)$ & $(0.001)$ & $(0.001)$ \\
Observations & 29,938 & 29,938 & 29,938 & 23,604 \\
$R$-squared & 0.066 & 0.298 & 0.331 & 0.333
\end{tabular}

Panel B: Literacy skill use at work

$\begin{array}{lllll}\text { Female } & 0.060^{*} & -0.088^{* * *} & -0.077^{* * *} & -0.078^{* *} \\ & (0.031) & (0.025) & (0.025) & (0.030) \\ \text { Has a partner } & 0.270^{* * *} & 0.127^{* * *} & 0.078^{* *} & 0.065^{*} \\ & (0.030) & (0.026) & (0.031) & (0.034) \\ \text { Partner*female } & -0.089^{* *} & -0.069^{*} & -0.053 & -0.034 \\ & (0.044) & (0.040) & (0.040) & (0.045) \\ \text { Hours worked } & 0.014^{* * *} & 0.012^{* * *} & 0.011^{* * *} & 0.011^{* * *} \\ & (0.001) & (0.001) & (0.001) & (0.001) \\ \text { Hours spent on housework } & -0.024^{* * *} & -0.005^{* *} & -0.003 & -0.003 \\ & (0.002) & (0.002) & (0.002) & (0.002) \\ \text { Hours spent on family care } & 0.003^{* * *} & 0.001 & 0.001 & 0.002 \\ & (0.001) & (0.001) & (0.001) & (0.001) \\ \text { Observations } & 30,955 & 30,955 & 30,955 & 24,288 \\ R \text {-squared } & 0.101 & 0.354 & 0.389 & 0.397 \\ \text { Panel C: ICT skill use at work } & & & & \\ \text { Female } & & & & \\ \text { Has a partner } & -0.058^{*} & -0.025 & -0.011 & 0.020 \\ \text { Partner*female } & (0.032) & (0.028) & (0.028) & (0.032) \\ & 0.193^{* * *} & 0.125^{* * *} & 0.152^{* * *} & 0.146^{* * *} \\ & (0.032) & (0.028) & (0.033) & (0.036) \\ & -0.041 & -0.064^{*} & -0.079 * * & -0.106^{* *} \\ & (0.038) & (0.035) & (0.035) & (0.044)\end{array}$


Table 7 (continued)

(1)

(2)

(3)

(4)

PS matching

\begin{tabular}{lllll}
\hline Hours worked & $0.011 * * *$ & $0.011 * * *$ & $0.009 * * *$ & $0.009 * * *$ \\
Hours spent on housework & $(0.001)$ & $(0.001)$ & $(0.001)$ & $(0.001)$ \\
& $-0.019 * * *$ & $-0.009 * * *$ & $-0.007 * * *$ & $-0.005 *$ \\
Hours spent on family care & $(0.002)$ & $(0.002)$ & $(0.002)$ & $(0.002)$ \\
& $(0.002)$ & 0.001 & -0.000 & -0.000 \\
Observations & 25,701 & $(0.001)$ & $(0.001)$ & $(0.001)$ \\
$R$-squared & 0.083 & 0.320 & 25,701 & 20,004 \\
Country fixed effects & No & Yes & 0.353 & 0.368 \\
Country-occup. fixed effects & Yes & Yes & Yes & Yes \\
Other for job characteristics & No & No & Yes & Yes \\
\end{tabular}

Standard errors are in parentheses $* * * p<0.01, * * p<0.05, * p<0.1$. Control variables differ by column. Column (1) controls for country fixed effects. Column (2) controls for country-occupation fixed effects. Column (3) also controls for years of education and standardized literacy and numeracy test scores, partner dummy, experience, experience` 2, parents’ highest level of education, self-employment dummy, dummy for having a permanent contract, dummies for 1-digit industry, 5 firm size categories, private sector, dummy for those managing others, and trust in others. Column (4) shows the results estimated on the matched sample that uses propensity score matching (see the text for the details). Standard errors are calculated with the jackknife method (suggested by OECD (2013)) using 80 replication weights. All of the results are calculated by using sampling weights provided by the survey

negative relationship between housework and skill use at work. The gender gap in skill use among single individuals decreased also somewhat after controlling for time allocation compared to Table 6. Based on these results, we conclude that the unequal division of housework plays a key role in the gender gap in skill use at work among partnered individuals.

Gender differences in preferences It is possible that it is not the partnership status but the individual preferences toward skill use that decrease the skill use at work and increase the housework hours of partnered women. In other words, partnered women may prefer to use skills less than single women. Similarly, partnered women may do more housework than single women because they dis-prefer housework less. If this was the main mechanism, then (i) the skill use penalty of partnered women would disappear once we control for preferences and (ii) housework would not affect skill use at work conditional on skill use preferences.

As we cannot observe preferences directly, we proxy them with cognitive skill use in leisure time. We assume that individuals prefer to use skills more if they use their cognitive skills more in their leisure time. ${ }^{18}$

\footnotetext{
${ }^{18}$ The actual differences in skill use in leisure time over-control for the effect of housework and the gender gap in skill use at work. First, we only observe the segment level average of housework but we observe the
} 
The results are presented in Table 15. Columns (1) and (2) show that partnered women use cognitive skills less than men even conditional on skill use in leisure time. Furthermore, columns (3) and (4) reveal that the gender gap among partnered women decreases if we include housework hours into the regression. Based on these estimates, we concluded that it is not the differences in skill use preferences that drive our main results.

\subsection{Statistical discrimination against women}

In this section, we investigate whether statistical discrimination against women can explain their lower skill use. The idea is that the employer has discriminative assumptions about certain characteristics of women and that is why they assign less skill-intensive tasks to them. The first discriminative assumption we test is that employers assume that women have inferior cognitive skills compared to men. The second type of discrimination we investigate is based on the fertility rate of specific cohorts. This exercise is motivated by recent studies showing that women who have higher fertility rates based on their education, age, and marital status earn less (Yip and Wong 2014; Jessen et al. 2019) and are less likely to be hired for part-time jobs (Becker et al. 2019).

Discriminative assumptions about cognitive skills Altonji and Pierret (2001) studied this issue and found that employers cannot observe individual skills at the beginning of their workers' career, but firms can learn over time and get information about individual skills. As a consequence, firms discriminate less and less over time based on easily observable characteristics. It follows from their argument that cognitive skills have an increasing effect on skill use at work as time goes on, while easily observable characteristics (e.g., gender) have a decreasing effect. We can also formalize the argument and estimate the following regression:

$y_{i}=\beta_{0}+\beta_{1} *$ female $_{i}+\beta_{2} *$ female $_{i} * \exp _{i}+\beta_{3} * \operatorname{skill}_{i}+\beta_{4} * \operatorname{skill}_{i} * \exp _{i}+\gamma * X_{i}+u_{i}$

As in Eq. 2, the dependent variable is cognitive skill use at work. Exp denotes the labor market experience of workers while skill $i$ denotes the cognitive test scores. If women are discriminated against because they are assumed to have lower skills, then $\beta_{4}$ is positive and $\beta_{2}$ increases once we add $\beta_{4}$ to the regression (Altonji and Pierret 2001).

The estimation results are shown in Table 8. Contrary to the predictions of this mechanism, the effect of skills does not increase with experience. The interaction of the test score is never significant at the 5 percent level and the point estimates are very close to zero (10 years of experience would increase the effect of the numeracy

actual individual skill use in leisure time (Bollinger 2003). Second, there may be reserve causality if skill use at leisure time and at the workplace is complement 
Table 8 Discriminative assumptions about cognitive skills

\begin{tabular}{|c|c|c|c|c|c|c|}
\hline & (1) & (2) & (3) & (4) & (5) & (6) \\
\hline & \multicolumn{2}{|c|}{ Numeracy skill use } & \multicolumn{2}{|c|}{ Literacy skill use } & \multicolumn{2}{|l|}{ ICT skill use } \\
\hline Years of educ. & $\begin{array}{l}0.053 * * * \\
(0.003)\end{array}$ & $\begin{array}{l}0.053 * * * \\
(0.003)\end{array}$ & $\begin{array}{l}0.119 * * * \\
(0.004)\end{array}$ & $\begin{array}{l}0.119 * * * \\
(0.004)\end{array}$ & $\begin{array}{l}0.076^{* * * *} \\
(0.004)\end{array}$ & $\begin{array}{l}0.076 * * * \\
(0.004)\end{array}$ \\
\hline Female & $\begin{array}{l}-0.229 * * * \\
(0.030)\end{array}$ & $\begin{array}{l}-0.240 * * * \\
(0.031)\end{array}$ & $\begin{array}{l}-0.174 * * * \\
(0.027)\end{array}$ & $\begin{array}{l}-0.184 * * * \\
(0.028)\end{array}$ & $\begin{array}{l}-0.279 * * * \\
(0.034)\end{array}$ & $\begin{array}{l}-0.286^{* * *} \\
(0.035)\end{array}$ \\
\hline Experience & $\begin{array}{l}0.000 \\
(0.001)\end{array}$ & $\begin{array}{l}0.001 \\
(0.001)\end{array}$ & $\begin{array}{l}-0.001 \\
(0.001)\end{array}$ & $\begin{array}{l}-0.001 \\
(0.001)\end{array}$ & $\begin{array}{l}0.002 \\
(0.001)\end{array}$ & $\begin{array}{l}0.002 \\
(0.001)\end{array}$ \\
\hline Female*exp. & $\begin{array}{l}0.002 \\
(0.001)\end{array}$ & $\begin{array}{l}0.001 \\
(0.001)\end{array}$ & $\begin{array}{l}0.008 * * * \\
(0.001)\end{array}$ & $\begin{array}{l}0.007 * * * \\
(0.001)\end{array}$ & $\begin{array}{l}0.000 \\
(0.001)\end{array}$ & $\begin{array}{l}-0.000 \\
(0.001)\end{array}$ \\
\hline Numeracy test & $\begin{array}{l}0.211 * * * \\
(0.030)\end{array}$ & $\begin{array}{l}0.156 * * * \\
(0.037)\end{array}$ & $\begin{array}{l}0.062 * * * \\
(0.021)\end{array}$ & $\begin{array}{l}0.010 \\
(0.042)\end{array}$ & $\begin{array}{l}0.076 * * * \\
(0.026)\end{array}$ & $\begin{array}{l}0.043 \\
(0.043)\end{array}$ \\
\hline Num. test*exp. & & $\begin{array}{l}0.003 * \\
(0.002)\end{array}$ & & $\begin{array}{l}0.003^{*} \\
(0.002)\end{array}$ & & $\begin{array}{l}0.002 \\
(0.002)\end{array}$ \\
\hline Literacy test & $\begin{array}{l}-0.020 \\
(0.032)\end{array}$ & $\begin{array}{l}0.009 \\
(0.039)\end{array}$ & $\begin{array}{l}0.035 \\
(0.021)\end{array}$ & $\begin{array}{l}0.055 \\
(0.041)\end{array}$ & $\begin{array}{l}0.064 * * \\
(0.026)\end{array}$ & $\begin{array}{l}0.080 * \\
(0.043)\end{array}$ \\
\hline Lit. test*exp. & & $\begin{array}{l}-0.002 \\
(0.002)\end{array}$ & & $\begin{array}{l}-0.001 \\
(0.002)\end{array}$ & & $\begin{array}{l}-0.001 \\
(0.002)\end{array}$ \\
\hline Observations & 30,263 & 30,263 & 31,277 & 31,277 & 25,931 & 25,931 \\
\hline$R$-squared & 0.103 & 0.103 & 0.183 & 0.184 & 0.112 & 0.113 \\
\hline
\end{tabular}

The table shows the point estimates for Eq. 3. Standard errors are in parentheses ${ }^{* * *} p<0.01,{ }^{* *} p<0.05$, ${ }^{*} p<0.1$. The dependent variables are shown at the top of the column. We follow the strategy of Altonji and Pierret (2001) and we do not use additional controls except the country dummies. Standard errors are calculated with the jackknife method (suggested by OECD (2013)) using 80 replication weights. All of the results are calculated by using sampling weights provided by the survey

test score on numeracy skill use at work by 0.03 standard deviation). ${ }^{19}$ Furthermore, the gender gap in skill use does not decrease faster once we control for the dynamic effects of cognitive skills. We conclude that women are not assigned tasks requiring lower skills because they are assumed to have inferior skills.

Discrimination based on expected rate of childbirth Some employers may offer less skill-intensive tasks to workers who are expected to stay with the firm for a shorter period of time. As a consequence, employers may discriminate against women because they are more likely to exit the firm for maternity leave. To test this hypothesis, we organize workers in labor market segments by country, education, and age, and merge the segment-specific birth rates from the Human Fertility Database (HFD

\footnotetext{
${ }^{19}$ Another possibility is that firms do not learn about the skills of individuals. However, this conclusion would be in strong contrast with previous literature on employer learning (Lange 2007; Schönberg 2007; Arcidiacono et al. 2010; Rockoff et al. 2012).
} 
Human fertility database 2020). ${ }^{20}$ Using the merged database, we run the following regression:

$$
y_{i}=\beta_{0}+\beta_{1} * \text { female }_{i}+\beta_{2} * \text { fertility }_{c}+\beta_{3} * \text { female }_{i} * \text { fertility }_{c}+\gamma * X_{i}+u_{i}
$$

Again, the left hand-side variables are the skill use indices at work. Fertility $y_{c}$ denotes country-education-age specific birth rates, while $X_{i}$ are the same control variables as in Eq. 2. The parameter of fertility ${ }_{c}$ measures the effect of women's fertility rate on men in the same demographic segment. ${ }^{21}$ This parameter can even be positive if firms allocate the skill-intensive tasks from women to men more in higher fertility rate segments. ${ }^{22}$ Our main variable of interest is $\beta_{3}$, which is negative if women of a larger fertility rate cohort are assigned less skill-intensive tasks. We consider this parameter as the measure of statistical discrimination, as it shows the effect of the average behavior of the labor market segment on individual outcomes.

The point estimates for Eq. 4 show mixed results (Table 9). The estimated effect of women's fertility rate on men $\left(\beta_{2}\right)$ varies a lot between the skill use indices and they are highly sensitive to the inclusion of control variables but are mostly positive. As the average fertility rate in our sample is 0.03 , the estimated parameters seem to have a very low effect on the skill use of men.

Turning to the main variable of interest, column (2) shows that the fertility rate decreases the numeracy skill use of women compared to men of the same age and educational level. Again, the point estimates are low, as the gender gap in skill use would decrease only by $0.823 * 0.03=0.024$ if the birth rate decreased to zero. Moreover, column (4) reveals that the birth rate does not decrease the literacy skill use of women significantly. The point estimate is negative but statistically not different from zero ( coef. -0.679 s.e 0.485 ). Finally, we do not find a significant negative relationship between the fertility rate and ICT skill use of women (coeff 0.852 s.e. 0.465 ) even if we control for individual characteristics in column (6). Based on these results, we conclude that discrimination based on cohort-specific fertility rates cannot explain the gender gap in skill use.

\section{Discussion}

In this section, we discuss the possible mechanisms which lead to negative correlation between housework and skill use at workplace and to a larger gender penalty in skill use among partnered individuals.

Individuals may have a capacity constraint on effort and they have to divide their effort between housework and using skills at the workplace. In other words,

\footnotetext{
${ }^{20}$ Note: The age-specific fertility rate differs country by country and educational level; that is why it is not sufficient to examine the age specific gender gap in skill use.

${ }^{21}$ As the fertility rate is defined for women only, we merge women's fertility by country-education-age to the data. For example, in the case of a 27-year-old Italian man with a university degree, this parameter shows the effect of the fertility rate of a similar Italian woman (27-year-old, with a university degree).

${ }^{22}$ This may be the case if old and young workers of the same educational level are not perfect substitutes (Card and Lemieux 2001), but women and men of the same age and skills are close substitutes.
} 
Table 9 The effect of birth rate on the gender gap in skill use

\begin{tabular}{lllllll}
\hline & $(1)$ & $(2)$ & $(3)$ & $(4)$ & $(5)$ & $(6)$ \\
& Numeracy skill use & Literacy skill use & ICT skill use & \\
\hline Female & $-0.311^{* * *}$ & $-0.140^{* * *}$ & $-0.353^{* * *}$ & $-0.193 * * *$ & $-0.335^{* * *}$ & $-0.163 * * *$ \\
& $(0.028)$ & $(0.027)$ & $(0.025)$ & $(0.027)$ & $(0.024)$ & $(0.027)$ \\
Fertility rate & 0.521 & $1.133 * * *$ & $-1.663 * * *$ & $1.409 * * *$ & 0.407 & $1.055^{* * * *}$ \\
& $(0.366)$ & $(0.371)$ & $(0.367)$ & $(0.428)$ & $(0.393)$ & $(0.380)$ \\
Fertility rate* & -0.194 & $-0.823 * *$ & $0.980 *$ & -0.679 & $1.785 * * *$ & $0.852 *$ \\
Female & $(0.522)$ & $(0.404)$ & $(0.498)$ & $(0.485)$ & $(0.493)$ & $(0.465)$ \\
Controls & & Yes & & Yes & & Yes \\
Observations & 21,130 & 21,130 & 21,130 & 21,130 & 21,130 & 21,130 \\
$R$-squared & 0.025 & 0.223 & 0.028 & 0.207 & 0.022 & 0.273 \\
\hline
\end{tabular}

The table shows the point estimates for Eq. 4. Standard errors are in parentheses ${ }^{* * *} p<0.01,{ }^{* *} p<0.05$, ${ }^{*} p<0.1$. The dependent variables are shown at the top of the column. The control variables are the same as in Table 5: partner dummy, child dummy, years of education, experience, experiencê 2, numeracy and literacy test scores, occupation categories (ISCO 3-digit), country fixed effects, parents' highest level of education and parents' immigration status, dummy for full time work, self-employment dummy, dummy for having a permanent contract, dummies for 1-digit industry, 5 firm size categories, private sector. Standard errors are calculated with the jackknife method (suggested by OECD (2013)) using 80 replication weights. All of the results are calculated by using sampling weights provided by the survey

individuals who exert high effort at the workplace cannot devote high effort to housework as well. For example, workers doing a lot of overtime at the workplace have less time to spend on housework. Similarly, individuals doing a lot of housework can use their cognitive skills less at the workplace. In line with this explanation, partners are shown to divide housework duties unequally. Table 4 shows that the gender difference in housework hours is much smaller among single people than among people who live with a partner.

Several channels can lead simultaneously to the unequal division of housework. The most widespread explanation says that individuals disprefer doing housework and that is why partners bargain about its allocation. As men usually earn more than women, they have stronger bargaining power and end up doing less housework (Bittman et al. 2003; Baxter and Hewitt 2013). However, other papers frame (Becker 1985; Hersch and Stratton 1994) the division of housework as a matter of specialization. They argue that specialization in specific tasks (housework or work at the workplace) increases marginal productivity and broadens the Pareto frontier of the household. In this framework, women do more housework to improve the total utility of the household and not because of bargaining constraints. If bargaining caused the unequal division of housework, then women would prefer to do less housework than they actually do while if specialization is the main reason, then women are at the optimum and they do not prefer an alternative division. The third explanation of the unequal division of housework is the "doing gender" hypothesis (Álvarez 2003; Kroska 2004; Lalive and Stutzer 2010; Sevilla-Sanz et al. 2010). This hypothesis says 
that it is the social norms which force women to do more housework. Thus, ceteris paribus, women do more housework than men because society expects them to do so independently from their individual or household characteristics.

Finally, it is possible that it is not the interactions among partners per se that affects the gender gap in skill use but rather having children alters the equal division of housework within a partnership. In line with this, having children is shown to be a key driver of gender inequality (Angelov et al. 2016; Kleven et al. 2019).

We investigate this mechanism in Appendix Table 16. In these regressions, we control for partnership status and time allocation of the respondents. If having children is the main driver of the gender gap in skill use at work, then we expect a negative parameter for the interaction for female and children. The negative parameter means that women with children use their cognitive skills less than men with children even conditional on partnership status and condition on housework. As opposed to this, Appendix Table 16 shows no significant parameter in any of the skill use indices once we control for occupation as well.

\section{Conclusion}

Although a large body of empirical literature documents the gender differences prevailing on the labor market, we know much less about what people actually do at their workplace and what causes the within-occupation gender differences. To the best of our knowledge, we are the first to document within-occupation differences in skill use and to examine the underlying mechanisms at the same time.

By using an international survey (PIAAC-Programme for the International Assessment of Adult Competencies) that provides detailed information on tasks performed during work, we found that women report significantly lower levels of numeracy and computer skill usage, and they also read and write significantly less at the workplace than men. This finding is robust against taking into account composition effects (demographic and firm characteristics, different levels of education, and experience) and controlling for differences in cognitive test scores. Conversely, we find that women living in partnership use their cognitive skills less than men with partners.

We argue that the unequal division of housework is an important confounder of the results. Women living in partnership do more housework than single women. However, living with a partner has a much weaker effect on skill use of women conditional on housework. In our interpretation, these results mean that workers have to divide their effort between housework and skill use at work. Furthermore, women living in a partnership increase their effort spent on housework at the cost of lower skill use at work. We also showed that individual preferences toward skill use cannot explain the empirical findings and we do not find evidence of statistical discrimination in task allocation either.

Finally, our results imply that the division of housework has an effect on labor market outcomes; therefore, policies which aim to decrease gender segregation between occupations cannot fully eliminate gender differences on the labor market. However, further research is needed to explain why women in a partnership and single women 
with children put in more housework hours compared to men and single women without children.

\section{Appendix}

Table 10 The construction of skill use indices

\begin{tabular}{|c|c|}
\hline Cognitive skill use indices & Non-cognitive skill use indices \\
\hline Index of use of numeracy skills at work & Index of use of planning skills at work \\
\hline How often-calculating costs or budgets & How often-planning own activities \\
\hline $\begin{array}{l}\text { How often-use or calculate fractions or } \\
\text { percentages }\end{array}$ & How often-planning others' activities \\
\hline How often-use a calculator & How often-organizing own time \\
\hline \multicolumn{2}{|l|}{ How often-prepare charts, graphs, or tables } \\
\hline How often-use simple algebra or formulas & Index of use of influencing skills at work \\
\hline How often-use advanced math or statistics & How often-teaching people \\
\hline \multirow[t]{2}{*}{ How often-presentations } & How often-presentations \\
\hline & How often-advising people \\
\hline Index of use of writing skills at work & How often-planning others' activities \\
\hline How often-write letters memos or mails & How often-influencing people \\
\hline How often-write articles & How often-negotiating with people \\
\hline \multicolumn{2}{|l|}{ How often-write reports } \\
\hline \multirow[t]{2}{*}{ How often-fill in forms } & Index of learning at work \\
\hline & How often-learning from co-workers/supervisors \\
\hline Index of use of reading skills at work & How often-learning-learning-by-doing \\
\hline How often-read directions or instructions & How often-learning — keeping up to date \\
\hline \multicolumn{2}{|l|}{ How often-read letters memos or mails } \\
\hline How often-read newspapers or magazines & Index of use of task discretion at work \\
\hline $\begin{array}{l}\text { How often-read professional journals or } \\
\text { publications }\end{array}$ & Work flexibility—sequence of tasks \\
\hline How often-read books & Work flexibility—how to do the work \\
\hline How often—read manuals or reference materials & Work flexibility—speed of work \\
\hline How often-read financial statements & Work flexibility—working hours \\
\hline \multicolumn{2}{|l|}{ How often-read diagrams maps or schematics } \\
\hline \multicolumn{2}{|l|}{ Index of use of ICT skills at work } \\
\hline \multicolumn{2}{|l|}{ How often—for mail } \\
\hline \multicolumn{2}{|l|}{ How often-work related info } \\
\hline \multicolumn{2}{|l|}{ How often-conduct transactions } \\
\hline \multicolumn{2}{|l|}{ How often-spreadsheets } \\
\hline \multicolumn{2}{|l|}{ How often-real-time discussions } \\
\hline How often-word processor, e.g., Word & \\
\hline
\end{tabular}


Table 11 Descriptive statistics of the main variables for unemployed people

\begin{tabular}{lllll}
\hline Variable & Male & Female & Difference & $t$-stat \\
\hline Experience (year) & 13.81 & 11.89 & -1.91 & -3.30 \\
& 0.41 & 0.41 & & \\
Years of education & 11.01 & 11.90 & 0.89 & 5.01 \\
Share of those who have children & 0.13 & 0.12 & & 2.33 \\
under age of 18 & 0.10 & 0.13 & 0.04 & \\
Native & 0.01 & 0.01 & & \\
& 0.78 & 0.80 & 0.02 & \\
Average numeracy test score* & 0.02 & 0.01 & & \\
& 0.02 & -0.02 & -0.04 & \\
Average literacy test score* & 0.04 & 0.03 & & \\
& -0.03 & 0.03 & 0.06 & \\
Obs. & 0.04 & 0.03 & & \\
\hline
\end{tabular}

*Standardized test score with a mean of 0 and a variance of 1 . The standardization was made within the unemployed sample 
Table 12 Gender gap in skill use at work—seemingly unrelated regressions

\begin{tabular}{|c|c|c|c|c|}
\hline & (1) & (2) & (3) & (4) \\
\hline & \multicolumn{4}{|c|}{ Seemingly unrelated regression } \\
\hline & Numeracy & Literacy & ICT skill & Mean effect \\
\hline \multicolumn{5}{|l|}{ Panel A: Without controls } \\
\hline Gender gap & $\begin{array}{l}-0.322 * * * \\
(0.013)\end{array}$ & $\begin{array}{l}-0.242 * * * \\
(0.011)\end{array}$ & $\begin{array}{l}-0.271 * * * \\
(0.013)\end{array}$ & $\begin{array}{l}-0.263 * * * \\
(0.009)\end{array}$ \\
\hline Observations & 23,762 & 23,762 & 23,762 & 23,762 \\
\hline$R$-squared & 0.035 & 0.050 & 0.052 & \\
\hline Country fixed effects & Yes & Yes & Yes & Yes \\
\hline Counry-occup. fixed effects & No & No & No & No \\
\hline Controls & No & No & No & No \\
\hline \multicolumn{5}{|l|}{ Panel B: With controls } \\
\hline Gender gap & $\begin{array}{l}-0.193 * * * \\
(0.014)\end{array}$ & $\begin{array}{l}-0.177^{* * *} \\
(0.011)\end{array}$ & $\begin{array}{l}-0.126^{* * *} \\
(0.013)\end{array}$ & $\begin{array}{l}-0.175^{* * *} \\
(0.009)\end{array}$ \\
\hline Observations & 23,762 & 23,762 & 23,762 & 23,762 \\
\hline$R$-squared & 0.210 & 0.209 & 0.279 & \\
\hline Country fixed effects & Yes & Yes & Yes & Yes \\
\hline Counry-occup. fixed effects & Yes & Yes & Yes & Yes \\
\hline Controls & Yes & Yes & Yes & Yes \\
\hline Other for job characteristics & Yes & Yes & Yes & Yes \\
\hline
\end{tabular}

Standard errors are in parentheses *** $p<0.01, * * p<0.05, * p<0.1$. The table reproduces Table 5 on the subsample where every skill use index is observed. Columns (1)-(3) estimate the gender gap in skill use jointly for the three skill use indices with seemingly unrelated regression. Column (4) estimates the mean gender difference with the method of Lavy et al. (2016). Panel A controls only for country fixed effects while panel B uses all controls as in Table 5, column (3). Table 12 shows that the results do not change significantly if we consider only those respondents for whom every skill use index is available 
Table 13 Non-cognitive skill use at work
(1)

(2)

(3)

(4)

PS matching

Panel A: Use of planning skills at work

$\begin{array}{lllll}\text { Gender gap } & -0.180^{* * *} & -0.130^{* * * *} & -0.041^{* *} & -0.021 \\ & (0.016) & (0.017) & (0.017) & (0.016) \\ \text { Years of education } & & & 0.015^{* * *} & 0.016^{* * *} \\ & & (0.004) & (0.004) \\ \text { Literacy test scores } & & 0.022 & 0.024 * \\ & & (0.014) & (0.014) \\ \text { Numeracy test scores } & & & 0.042^{* * *} & 0.037 * * \\ & & & (0.015) & (0.017) \\ \text { Observations } & 36,798 & 36,798 & 36,798 & 28,997 \\ R \text {-squared } & 0.068 & 0.254 & 0.339 & 0.349\end{array}$

Panel B: Use of influencing skills at work

\begin{tabular}{|c|c|c|c|c|}
\hline Gender gap & $\begin{array}{l}-0.246^{* * *} \\
(0.022)\end{array}$ & $\begin{array}{l}-0.236^{* * *} \\
(0.021)\end{array}$ & $\begin{array}{l}-0.151^{* * *} \\
(0.019)\end{array}$ & $\begin{array}{l}-0.136^{* * *} \\
(0.017)\end{array}$ \\
\hline \multirow[t]{2}{*}{ Years of education } & & & $0.025 * * *$ & $0.027 * * *$ \\
\hline & & & $(0.004)$ & $(0.005)$ \\
\hline \multirow[t]{2}{*}{ Literacy test scores } & & & $-0.039 * *$ & -0.031 \\
\hline & & & $(0.018)$ & $(0.020)$ \\
\hline \multirow[t]{2}{*}{ Numeracy test scores } & & & $0.063 * * *$ & $0.048 * *$ \\
\hline & & & $(0.018)$ & $(0.022)$ \\
\hline Observations & 32,890 & 32,890 & 32,830 & 25,814 \\
\hline$R$-squared & 0.040 & 0.309 & 0.398 & 0.402 \\
\hline \multicolumn{5}{|c|}{ Panel C: use of task discretion at work } \\
\hline \multirow[t]{2}{*}{ Gender gap } & $-0.191 * * *$ & $-0.120 * * *$ & $-0.048 * * *$ & $-0.046^{* *}$ \\
\hline & $(0.016)$ & $(0.015)$ & $(0.015)$ & $(0.018)$ \\
\hline \multirow[t]{2}{*}{ Years of education } & & & $0.010 * *$ & $0.014 * * *$ \\
\hline & & & $(0.004)$ & $(0.005)$ \\
\hline \multirow[t]{2}{*}{ Literacy test scores } & & & 0.012 & -0.008 \\
\hline & & & $(0.017)$ & $(0.017)$ \\
\hline \multirow[t]{2}{*}{ Numeracy test scores } & & & 0.018 & 0.027 \\
\hline & & & $(0.017)$ & $(0.018)$ \\
\hline Observations & 35,383 & 35,383 & 35,383 & 27,839 \\
\hline$R$-squared & 0.061 & 0.231 & 0.316 & 0.317 \\
\hline
\end{tabular}


Table 13 (continued)
(1)
(2)
(3)
(4)
PS matching

Panel D: Use of learning skills at work

\begin{tabular}{lllll} 
Gender gap & $-0.130^{* * *}$ & $-0.117^{* * *}$ & $-0.093^{* * *}$ & $-0.085^{* * *}$ \\
& $(0.016)$ & $(0.017)$ & $(0.017)$ & $(0.019)$ \\
Years of education & & & $0.028^{* * *}$ & $0.031^{* * *}$ \\
& & & $(0.004)$ & $(0.004)$ \\
Literacy test scores & & 0.032 & 0.034 \\
& & & $(0.023)$ & $(0.022)$ \\
Numeracy test scores & & -0.005 & 0.001 \\
& & & $(0.023)$ & $(0.023)$ \\
Observations & 32,735 & 32,735 & 32,735 & 25,626 \\
0.124 & 0.246 & 0.280 & 0.308 & \\
& & & & \\
Country fixed effects & Yes & Yes & Yes & Yes \\
Counry-occup. fixed effects & No & Yes & Yes & Yes \\
Controls & No & No & Yes & Yes \\
Matched sample & No & No & No & Yes \\
\hline
\end{tabular}

Standard errors are in parentheses $* * * p<0.01, * * p<0.05, * p<0.1$. Control variables differ by column. Column (1) controls for country fixed effects. Column (2) controls for country-occupation fixed effects. Column (3) also controls for years of education and standardized literacy and numeracy test scores, partner dummy, experience, experience 2 , parents' highest level of education, self-employment dummy, dummy for having a permanent contract, dummies for 1-digit industry, 5 firm size categories, private sector, dummy for those managing others, and trust in others. Column (4) shows the results estimated on the matched sample that uses propensity score matching (see the text for the details). Standard errors are calculated with the jackknife method (suggested by OECD (2013)) using 80 replication weights. All of the results are calculated by using sampling weights provided by the survey 
Table 14 Gender gap in non-cognitive skill use at work—seemingly unrelated regressions

\begin{tabular}{|c|c|c|c|c|c|}
\hline & (1) & (2) & (3) & (4) & (5) \\
\hline & \multicolumn{5}{|c|}{ Seemingly unrelated regression } \\
\hline & Planning & Influencing & Task discretion & Learning & Mean effect \\
\hline \multicolumn{6}{|c|}{ Panel A: Without controls } \\
\hline Female & $\begin{array}{l}-0.184 * * * \\
(0.011)\end{array}$ & $\begin{array}{l}-0.271 \text { *** } \\
(0.012)\end{array}$ & $\begin{array}{l}-0.221^{* * *} \\
(0.011)\end{array}$ & $\begin{array}{l}-0.114 * * * \\
(0.011)\end{array}$ & $\begin{array}{l}-0.162 * * * \\
(0.008)\end{array}$ \\
\hline Observations & 29,169 & 29,169 & 29,169 & 29,169 & 29,169 \\
\hline$R$-squared & 0.087 & 0.046 & 0.072 & 0.131 & \\
\hline Country FE & Yes & Yes & Yes & Yes & Yes \\
\hline Cntry-occup. FE & No & No & No & No & No \\
\hline Controls & No & No & No & No & No \\
\hline \multicolumn{6}{|l|}{ Panel B: With controls } \\
\hline Female & $\begin{array}{l}-0.015 \\
(0.012)\end{array}$ & $\begin{array}{l}-0.168^{* * *} \\
(0.011)\end{array}$ & $\begin{array}{l}-0.071^{* * *} \\
(0.011)\end{array}$ & $\begin{array}{l}-0.0979^{* * *} \\
(0.012)\end{array}$ & $\begin{array}{l}-0.077 * * * \\
(0.007)\end{array}$ \\
\hline Observations & 29,169 & 29,169 & 29,169 & 29,169 & 29,169 \\
\hline$R$-squared & 0.285 & 0.360 & 0.257 & 0.227 & \\
\hline Country FE & Yes & Yes & Yes & Yes & Yes \\
\hline Country-occup. FE & Yes & Yes & Yes & Yes & Yes \\
\hline Controls & Yes & Yes & Yes & Yes & Yes \\
\hline Job charact. & Yes & Yes & Yes & Yes & Yes \\
\hline
\end{tabular}

Standard errors are in parentheses $* * * p<0.01, * * p<0.05, * p<0.1$. The table reproduces Table 13 on the subsample where every skill use index is observed. Columns (1)-(4) estimate the gender gap in skill use jointly for the four measures of non-cognitive skill use indices with seemingly unrelated regression. Column (4) estimates the mean gender difference with the method of Lavy et al. (2016). Panel A controls only for country fixed effects while panel B uses every control as in Table 5, column (3). Table 14 shows that the results do not change significantly if we consider only those respondents for whom every skill use index is available 
females

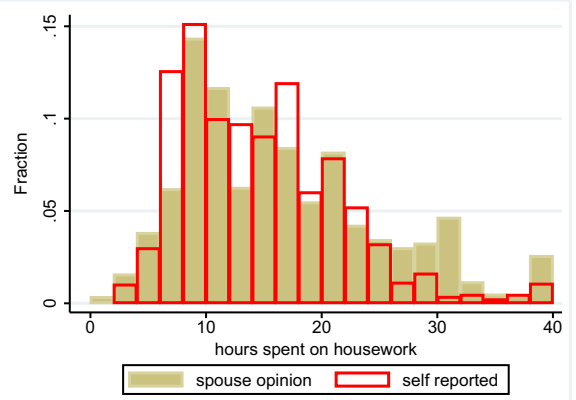

males

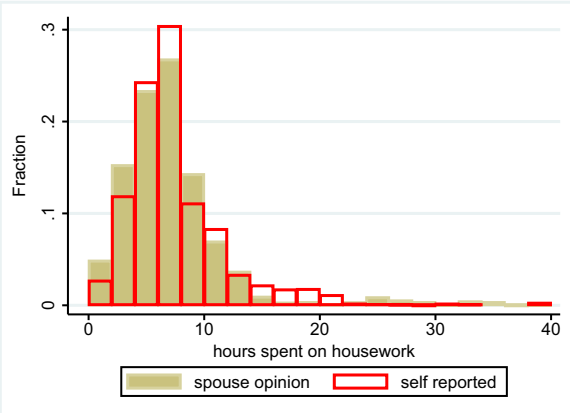

Fig. 2 Self-reported and spouse-reported hours spent on housework (weekly hours). The figure shows that the self-reported and spouse-reported hours spent on housework are similar. Single households are omitted and hours spent on housework are winsorized at 40 hours

Table 15 Gender gap in skill use at work and leisure time activities

(1)

(2)
(3)

(4)

PS matching

Panel A: Numeracy skill use at work

Female

$-0.132 * * *$
$(0.029)$
$0.224 * * *$
$(0.025)$
$-0.154 * * *$
$(0.032)$

$-0.081 * * *$

$-0.022$

$-0.003$

(0.028)

(0.028)

(0.032)

Has a partner

$0.131 * * *$

$0.073 * * *$

0.093 ***

(0.025)

(0.027)

(0.026)

Partner*female

Housework hours

$-0.109^{* * *}$

$-0.009$

$-0.014$

(0.030)

(0.034)

(0.034)

$-0.003$

$-0.004$

(0.003)

(0.003)

ICT skill use for leisure

$$
\begin{aligned}
& 0.119 * * * \\
& (0.013)
\end{aligned}
$$

$0.064 * * *$

$0.058 * * *$

$0.053 * * *$

(0.012)

(0.012)

(0.013)

Numeracy skill use for leisure

$0.273 * * *$

$0.246^{* * * *}$

$0.249 * * *$

$0.255^{* * * *}$

(0.013)

(0.012)

(0.011)

(0.012)

Reading skill use for leisure

$0.049 * *$

$0.094 * * *$

$0.092 * * *$

$0.093 * * *$

(0.022)

$-0.014$

(0.018)

(0.018)

(0.016)

Writing skill use for leisure

(0.018)

Observations

24,522

$R$-squared

0.145

0.007

0.014

0.003

(0.013)

(0.013)

24,425

24,425

19,194

0.355

0.401

0.404

Panel B: Literacy skill use at work

$\begin{array}{lllll}\text { Female } & 0.014 & -0.049 * & -0.012 & -0.011 \\ \text { Has a partner } & (0.032) & (0.027) & (0.026) & (0.027) \\ & 0.351 * * * & 0.181 * * * & 0.082 * * * & 0.073 * * \\ \text { Partner*female } & (0.028) & (0.024) & (0.027) & (0.029) \\ & -0.268 * * * & -0.139 * * * & -0.000 & 0.015 \\ & (0.039) & (0.032) & (0.032) & (0.032)\end{array}$


Table 15 (continued)

(1)

(2)

(3)

(4)

PS matching

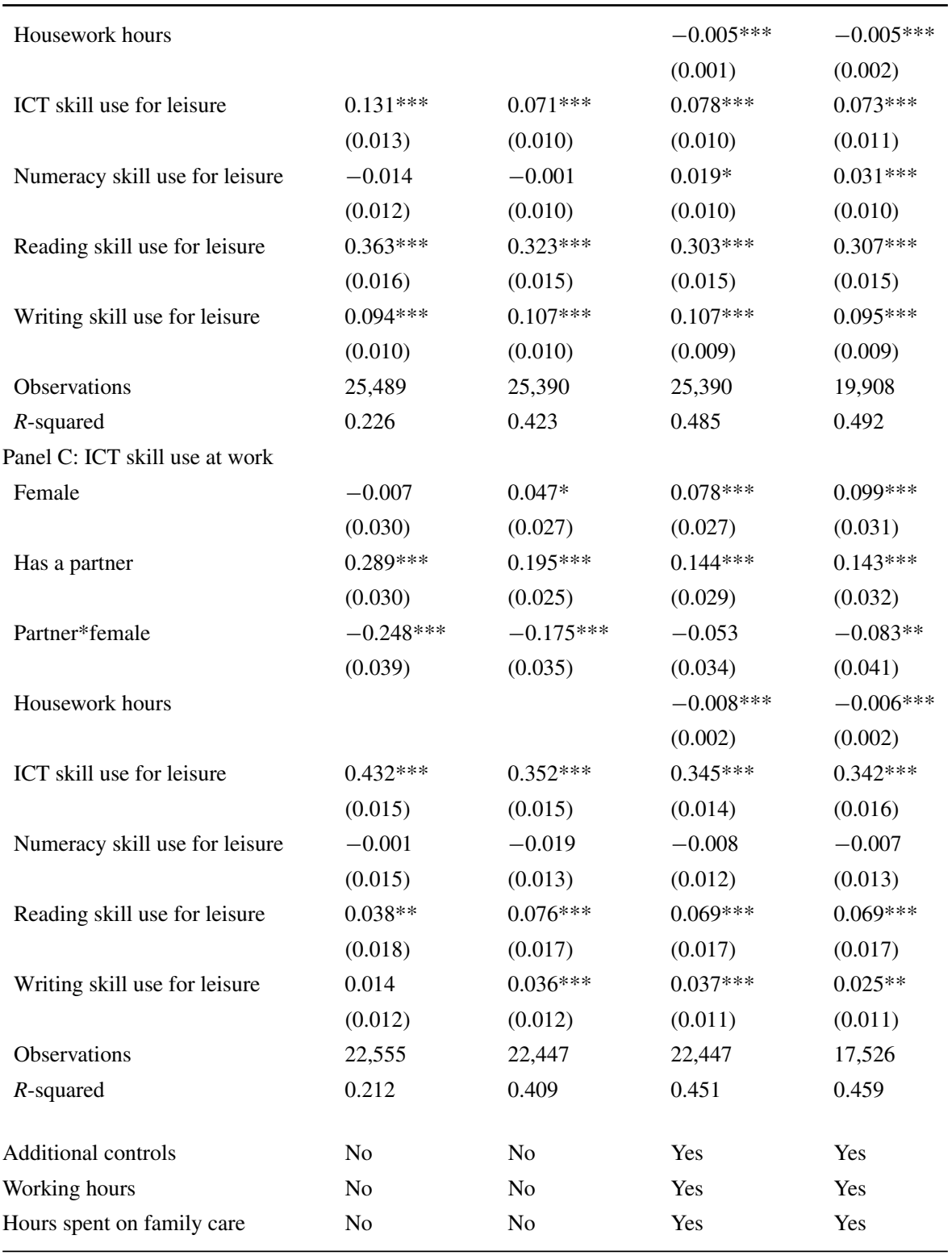

Standard errors are in parentheses $* * * p<0.01, * * p<0.05, * p<0.1$. Control variables differ by column. Column (1) controls for country fixed effects. Column (2) controls for country and on occupation fixed effects. Columns (3) and (4) use the same control as in Table 7. Standard errors are calculated with the jackknife method (suggested by OECD (2013)) using 80 replication weights. All of the results are calculated by using sampling weights provided by the survey 
Table 16 The effect of children on the gender gap

(1)

(2)

(3)

(4)

PS matching

Panel A: Numeracy skill use at work

Female

Has a partner

$-0.110^{* * * *}$

(0.028)

$0.160 * * *$

(0.024)

Partner*female

$-0.040$

$(0.042)$

Has a child

$-0.004$

$(0.033)$

Child $\times$ female

$0.203 * * *$

(0.060)

Observations

29,938

$R$-squared

0.068

Panel B: Literacy skill use at work

Female

$$
0.052 *
$$

$(0.031)$

Has a partner

$0.281 * * *$

(0.031)

Partner*female

$-0.100^{* *}$

(0.045)

Has a child

$-0.034$

(0.073)

Child $\times$ female

$0.146 * * *$

$(0.053)$

Observations

30,955

0.102

$R$-squared

Panel C: ICT skill use at work

Female

$-0.066^{* *}$

(0.032)

Has a partner

$0.181 * * *$

(0.032)

Partner*female

$-0.025$

(0.038)

Has a child

$0.144 * * *$

(0.045)

$-0.114 * * *$
$(0.025)$
$0.093 * * *$
$(0.021)$

$-0.057$

(0.037)

0.001

(0.032)

0.064

(0.042)

29,938

0.298

$-0.087^{* * *}$

(0.025)

$0.135 * * *$

$(0.025)$

$-0.080^{\text {** }}$

(0.039)

$-0.069$

$(0.050)$

0.025

(0.044)

30,955

0.355

$-0.030$

(0.028)

$0.110^{* * * *}$

(0.028)

$-0.044$

(0.037)

$0.130 * * *$

(0.038)

$-0.073 * * *$
$(0.025)$
$0.081 * * *$
$(0.022)$

-0.061 **

(0.030)

$0.072 * * *$

(0.026)

$-0.059^{*}$

(0.035)

$-0.030$

(0.034)

$-0.018$

(0.037)

$0.071^{*}$

(0.042)

23,604

0.333
$-0.073^{* *}$

(0.031)

$0.079 * *$

(0.031)

$-0.052$

(0.045)

$-0.113^{* *}$

(0.051)

0.003

(0.061)

24,291

0.400
0.390

$-0.015$

0.012

(0.028)

(0.033)

$0.142 * * *$

$0.133^{* * * *}$

(0.033)

(0.037)

$-0.065^{*}$

-0.090 *

(0.037)

(0.046)

$0.115^{* * * *}$

(0.038) 
Table 16 (continued)

(1) (2) (3) (4)

PS matching

\begin{tabular}{lllll}
\hline Child $\times$ female & 0.048 & -0.015 & -0.005 & 0.045 \\
& $(0.064)$ & $(0.055)$ & $(0.053)$ & $(0.055)$ \\
Observations & 25,701 & 25,701 & 25,701 & 20,003 \\
$R$-squared & 0.085 & 0.321 & 0.353 & 0.367 \\
& & & & \\
Time allocation & Yes & Yes & Yes & Yes \\
Country fixed effects & Yes & Yes & Yes & Yes \\
Country-occup. fixed effects & No & Yes & Yes & Yes \\
Other for job characteristics & No & No & Yes & Yes \\
\hline
\end{tabular}

Standard errors are in parentheses $* * * p<0.01, * * p<0.05, * p<0.1$. Control variables differ by column. Column (1) controls for country fixed effects. Column (2) controls for country-occupation fixed effects. Column (3) also controls for years of education and standardized literacy and numeracy test scores, partner dummy, experience, experience 2 , parents' highest level of education, self-employment dummy, dummy for having a permanent contract, dummies for 1-digit industry, 5 firm size categories, private sector, dummy for those managing others, and trust in others. Column (4) shows the results estimated on the matched sample that uses propensity score matching (see the text for the details). Standard errors are calculated with the jackknife method (suggested by OECD (2013)) using 80 replication weights. All of the results are calculated by using sampling weights provided by the survey 


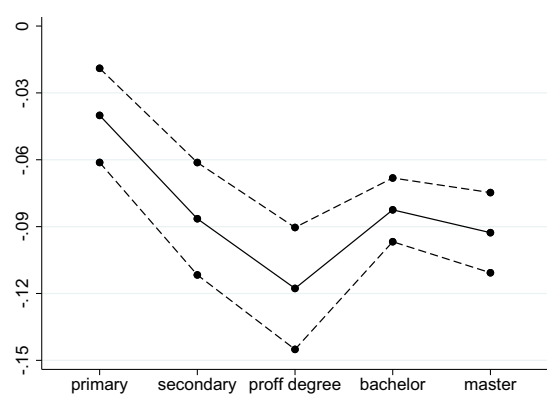

a
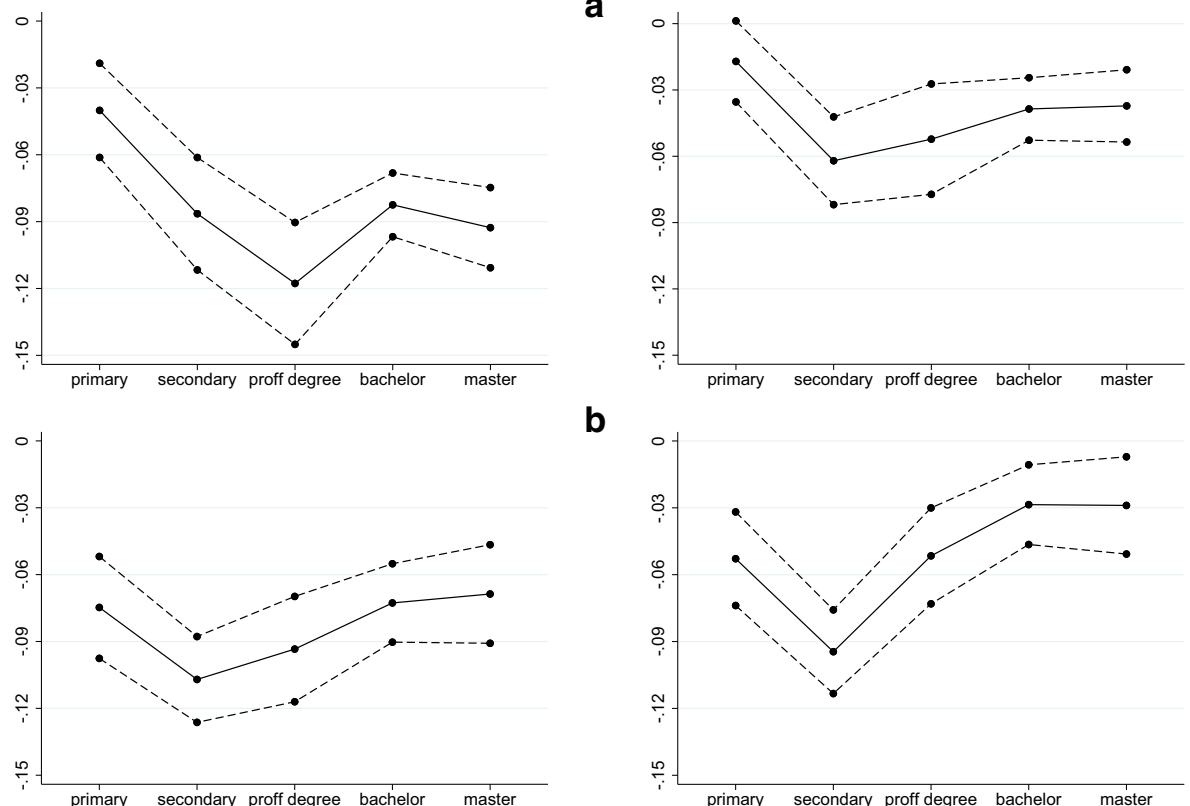

b
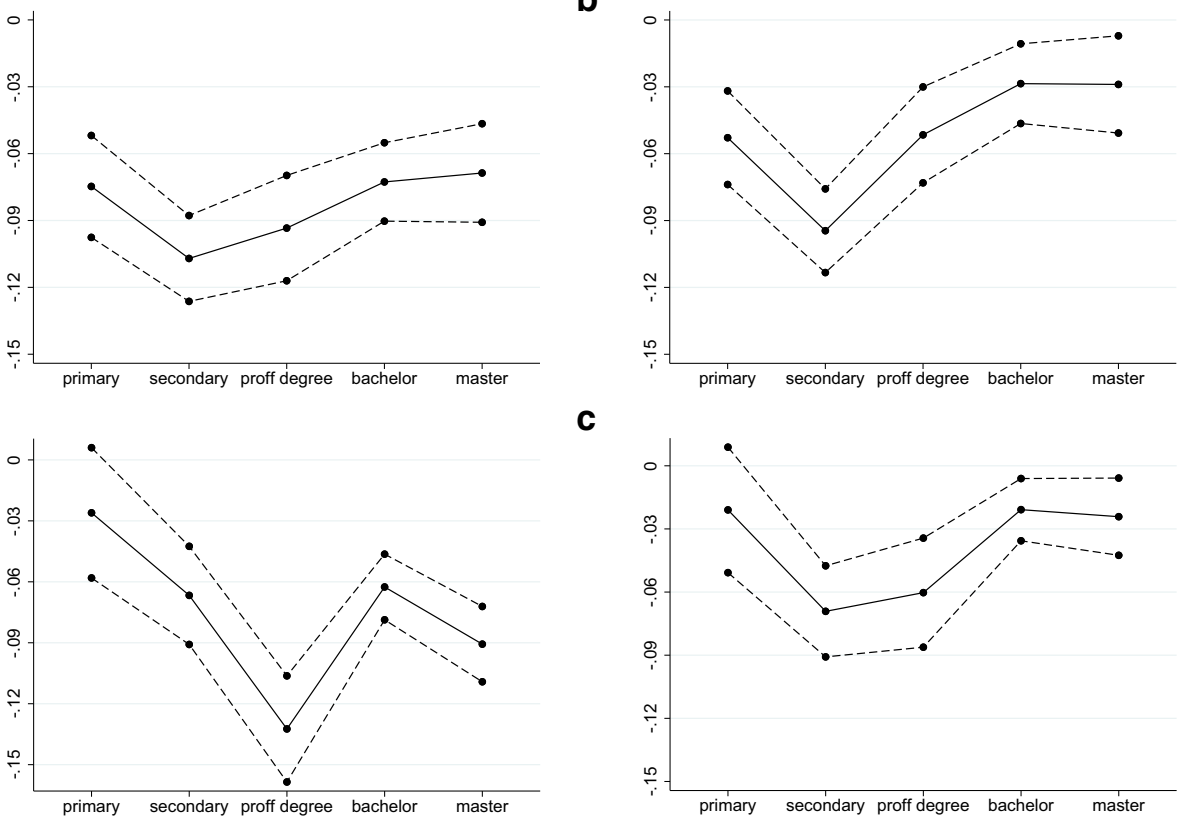

Fig. 3 The gender gap in skill use by educational level. The figure shows the gender gap in cognitive test scores by educational level. The figures on the left show the raw gap, while the figures on the right use partner dummy, child dummy, years of education, experience, experience ${ }^{\wedge} 2$, literacy and numeracy test scores, occupation categories (ISCO 3-digit), country fixed effects, parents' highest level of education and parents' immigration status, self-employment dummy, dummies for 1-digit industry, 5 firm size categories as control variables. Standard errors are calculated with the jackknife method (suggested by OECD (2013)) using 80 replication weights. All of the results are calculated by using sampling weights provided by the survey. a Gender gap in numeracy skill use at work, b Gender gap in literacy skill use at work c Gender gap in ICT skill use at work. The figures show the unconditional gap on left hand side, and the conditional gap on the right hand side 

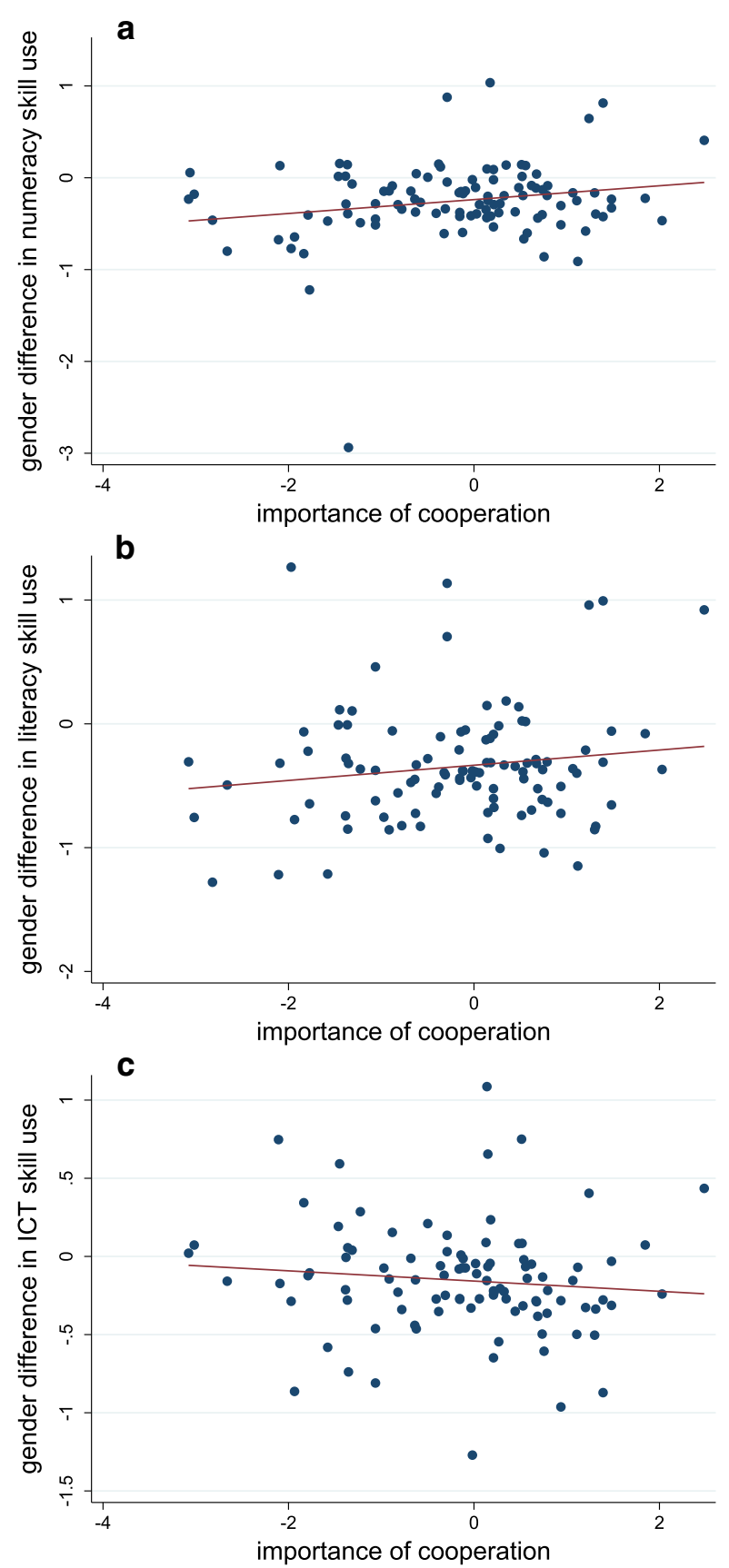

Fig. 4 Average skill use and gender gap test scores by occupations. a Numeracy skill use. b Literacy skill use. $\mathbf{c}$ Literacy skill use 
Acknowledgements We would like to thank Attila Gáspár, Győző Gyöngyössi, Hedvig Horváth, Gábor Kézdi, Attila Lindner, Balázs Muraközy, Ádám Szeidl, the editor, Shuaizhang Feng, the Managing Editor Madeline Zavodny, the two anonymous reviewers, and the audiences of the Central European University, MTA-KRTK, the 30th Eale Conference in Lyon, the ESPE Conference in Bath Workshop on Labour Economics in Trier, and the conference at Szirák. Balázs Reizer gratefully acknowledges the support of the Firms, Strategy and Performance Lendület Grant of the Hungarian Academy of Sciences and the MTA Premium Postdoctoral Research Program.

Funding Open access funding provided by ELKH Centre for Economic and Regional Studies.

\section{Declarations}

Conflict of interest The authors declare no conflict of interests.

Open Access This article is licensed under a Creative Commons Attribution 4.0 International License, which permits use, sharing, adaptation, distribution and reproduction in any medium or format, as long as you give appropriate credit to the original author(s) and the source, provide a link to the Creative Commons licence, and indicate if changes were made. The images or other third party material in this article are included in the article's Creative Commons licence, unless indicated otherwise in a credit line to the material. If material is not included in the article's Creative Commons licence and your intended use is not permitted by statutory regulation or exceeds the permitted use, you will need to obtain permission directly from the copyright holder. To view a copy of this licence, visit http://creativecommonshorg/licenses/by/4. $0 \%$.

\section{References}

Acemoglu D, Autor D (2011) Skills, tasks and technologies: implications for employment and earnings. Handbook of Labor Economics 4:1043-1171

Altonji JG, Pierret CR (2001) Employer learning and statistical discrimination. The Quarterly Journal of Economics 116(1):313-350

Álvarez B. (2003) D.miles Gender effect on housework allocation: evidence from spanish two-earner couples. J Popul Econ 16(2):227-242

Anderson ML (2008) Multiple inference and gender differences in the effects of early intervention: a reevaluation of the abecedarian, perry preschool, and early training projects, Journal of the American Statistical Association 103 (484)

Angelov N, Johansson P, Lindahl E (2016) Parenthood and the gender gap in pay. Journal of Labor Economics 34(3):545-579

Arcidiacono P, Bayer P, Hizmo A (2010) Beyond signaling and human capital: education and the revelation of ability. American Economic Journal:, Applied Economics 2(4):76-104

Autor D, Dorn D (2013) The growth of low-skill service jobs and the polarization of the us labor market. The American Economic Review 103(5):1553-1597

Autor DH, Handel MJ (2013) Putting tasks to the test: human capital, job tasks, and wages. J Labor Econ 31(S1):S59-S96

Baxter J, Hewitt B (2013) Negotiating domestic labor: women's earnings and housework time in australia. Fem Econ 19(1):29-53

Becker GS (1985) Human capital, effort, and the sexual division of labor. J Labor Econ 3:33-58

Becker SO, Fernandes A, Weichselbaumer D (2019) Discrimination in hiring based on potential and realized fertility: evidence from a large-scale field experiment. Labour Econ 59:139-152

Bittman M, England P, Sayer L, Folbre N, Matheson G (2003) When does gender trump money? bargaining and time in household work. Am J Sociol 109(1):186-214

Black SE, Spitz-Oener A (2010) Explaining women's success: technological change and the skill content of women's work. Rev Econ Stat 92(1):187-194

Blau FD, Kahn LM (2000) Gender differences in pay. J Econ Perspect 14(4):75-99 
Bollinger CR (2003) Measurement error in human capital and the black-white wage gap. Review of Economics and Statistics 85(3):578-585

Card D, Lemieux T (2001) Can falling supply explain the rising return to college for younger men? A cohort-based analysis. The Quarterly Journal of Economics 116(2):705-746

Christl M, Köppl-turyna M (2020) Gender wage gap and the role of skills and tasks: evidence from the austrian piaac data set. Appl Econ 52(2):113-134

Cobb-Clark DA, Tan M (2011) Noncognitive skills, occupational attainment, and relative wages. Labour Econ 18(1):1-13

Cortes GM, Jaimovich N, Siu HE (2018) The "end of men" and rise of women in the high-skilled labor market. Technical report, National Bureau of Economic Research

Cubas G, Juhn C, Silos P (2019) Coordinated work schedules and the gender wage gap. Technical report, National Bureau of Economic Research

Dela Rica S, Dolado JJ, Llorens V (2008) Ceilings or floors? gender wage gaps by education in spain. J Popul Econ 21(3):751-776

Deming D, Kahn LB (2018) Skill requirements across firms and labor markets: evidence from job postings for professionals. J Labor Econ 36(S1):S337-S369

Deming DJ (2017) The growing importance of social skills in the labor market. The Quarterly Journal of Economics 132(4):1593-1640

Elsayed A, Degrip A, Fouarge D (2017) Job tasks, computer use, and the decreasing part-time pay penalty for women in the uk. Br J Ind Relat 55(1):58-82

Goldin C (2014) A grand gender convergence: its last chapter. Am Econ Rev 104(4):1091-1119

Goldin C (2014) A pollution theory of discrimination: male and female differences in occupations and earnings. In: Human capital in history: the American record, pp. 313-348, University of Chicago Press

Goos M, Manning A, Salomons A (2009) Job polarization in europe. Am Econ Rev 99(2):58-63

Hampf F, Woessmann L (2017) Vocational vs. general education and employment over the life cycle: new evidence from piaac. CESifo Economic Studies 63(3):255-269

Hardy W, Keister R, Lewandowski P (2018) Educational upgrading, structural change and the task composition of jobs in europe. Economics of Transition 26(2):201-231

Heckman JJ, Humphries JE, Veramendi G (2018) Returns to education: the causal effects of education on earnings, health, and smoking. J Polit Econ 126(1):197-246

Hersch J, Stratton LS (1994) Housework, wages, and the division of housework time for employed spouses. The American Economic Review 84(2):120-125

Hersch J, Stratton LS (2002) Housework and wages. J Hum Resour, pp 217-229

HFD Human fertility database (2020) Max Planck Institute for Demographic Research (Germany) and Vienna Institute of Demography (Austria). Available at www.humanfertility.org

ISCO International standard classification of occupations (2008) Technical report, available at http://www. ilo.org/public/english/bureau/stat/isco/

ISSP International social survey programme (2019) Family and changing gender roles iv, available at https://doi.org/10.4232/1.12661

Jacob BA (2002) Where the boys aren't: non-cognitive skills, returns to school and the gender gap in higher education. Econ Educ Rev 21(6):589-598

Jessen J, Jessen R, Kluve J (2019) Punishing potential mothers? Evidence for statistical employer discrimination from a natural experiment. Labour Econ 59:164-172

Jimeno JF, Lacuesta A, Martínez-matute M, Villanueva E (2016) Education, labour market experience and cognitive skills: evidence from piaac. Banco de Espana Working Paper 1635

Kleven HJ, Landais NC, Søgaard JE (2019) Children and gender inequality: evidence from denmark, American Economic Journal: Applied Economics

Kroska A (2004) Divisions of domestic work: revising and expanding the theoretical explanations. J Fam Issues 25(7):890-922

Lalive R, Stutzer A (2010) Approval of equal rights and gender differences in well-being. J Popul Econ 23(3):933-962

Lange F (2007) The speed of employer learning. J Labor Econ 25(1):1-35

Lavy V, Lotti G, Yan Z (2016) Empowering mothers and enhancing early childhood investment: effect on adults outcomes and children cognitive and non-cognitive skills. Technical report, National Bureau of Economic Research

Miller AR, Segal C (2019) Do female officers improve law enforcement quality? Effects on crime reporting and domestic violence. Rev Econ Stud 86(5):2220-2247 
OECD (2012) Literacy, numeracy and problem solving in technology-rich environments: framework for the oecd survey of adult skills OECD Publishing

OECD (2013) Technical report of the survey of adult skills (piaac) OECD Publishing

OECD (2014) The survey of adult skills: reader's companion, OECD Publishing, available at https://doi. org/10.1787/9789264204027-en

Olivetti C, Petrongolo B (2016) The evolution of gender gaps in industrialized countries. Annual Review of Economics 8:405-434

O*NET (2018) Occupational information network, Technical report, US Department of Labor/Employment and Training Administration, downloaded from: https://www.onetonline.org/find/descriptor/ result/1.C.3.a? $\mathrm{a}=1$

Petô R., Reizer B (2021) Gender differences in skill content of jobs CERS-IE working paper -2021/2

Reskin B (1993) Sex segregation in the workplace. Annu Rev Sociol 19:241-270

Rockoff JE, Staiger DO, Kane TJ, Taylor ES (2012) Information and employee evaluation: evidence from a randomized intervention in public schools. Am Econ Rev 102(7):3184-3213

Schönberg U. (2007) Testing for asymmetric employer learning. J Labor Econ 25(4):651-691

Sevilla-Sanz A, Gimenez-Nadal JI, Fernández C (2010) Gender roles and the division of unpaid work in spanish households. Fem Econ 16(4):137-184

Spitz-Oener A (2006) Technical change, job tasks, and rising educational demands: looking outside the wage structure. J Labor Econ 24(2):235-270

Stinebrickner R, Stinebrickner T, Sullivan P (2019) Job tasks, time allocation, and wages. J Labor Econ 37(2):399-433

Stinebrickner TR, Stinebrickner R, Sullivan PJ (2018) Job tasks and the gender wage gap among college graduates, Working Paper 24790 National Bureau of Economic Research

Townsend RM, et al. (1994) Risk and insurance in village india. Econometrica 62:539-539

Weinberger CJ (2014) The increasing complementarity between cognitive and social skills. Review of Economics and Statistics 96(4):849-861

Wolfers J $(2006,5)$ Diagnosing discrimination: stock returns and ceo gender. Journal of the European Economic Association 4(2-3):531-541

Wooldridge JM (2010) Econometric analysis of cross section and panel data. MIT press, Cambridge

Yip CM, Wong RS-K (2014) Gender-oriented statistical discrimination theory: empirical evidence from the Hong Kong labor market. Research in Social Stratification and Mobility 37:43-59

Publisher's note Springer Nature remains neutral with regard to jurisdictional claims in published maps and institutional affiliations. 